FILOLOGIJA 72, Zagreb 2019.

UDK 811.163.42'282.2'366(497.571)

DOI https://dx.doi.org/10.21857/yrvgqtkk69

Izvorni znanstveni članak

Rukopis primljen 27. V. 2019.

Prihvaćen za tisak 23. IX. 2019.

Ivana Nežić

Odsjek za kroatistiku

Filozofski fakultet

Sveučilište u Rijeci

Sveučilišna avenija 4, HR-51000 Rijeka

irepac@ffri.hr

\title{
IZ MORFOLOGIJE JUŽNIH LABINSKIH GOVORA
}

Južni su labinski govori podskupina labinske skupine govora koja je dijelom središnjega istarskog poddijalekta ekavskoga dijalekta čakavskoga narječja. U radu se donosi prikaz osnovnih značajki morfološkoga sustava ove podskupine govora koju čini ukupno osamnaest mjesnih govora. Podatci su prikupljeni terenskim istraživanjem, a opis morfološkoga sustava uključuje analizu promjenjivih vrsta riječi: deklinaciju imenica, pridjeva, zamjenica i brojeva te konjugaciju glagola. Osim prikaza načina tvorbe pojedinih oblika promjenjivih riječi, donosi se i osvrt na morfonološke alternacije u oblicima u kojima su one zabilježene.

\section{Uvod}

Labinska je skupina govora jedna od četiriju skupina (uz pazinsku, žminjsku i boljunsku) od kojih se sastoji središnji istarski poddijalekt ekavskoga čakavskog dijalekta (Vranić 2005:37-44, 334). Recentnim je dijalektološkim istraživanjima ta skupina govora klasificirana na južnu, sjevernu i sjeveroistočnu podskupinu. Južnoj podskupini labinskih govora pripada osamnaest mjesnih govora (navedenih abecednim redoslijedom): Bartića, Brega, Brgoda, Brovinja, Crnih, Drenja, Kapelice, Koromašna, Rovnih, Salakovaca, Stanišova, Svetoga Lovreca, Svete Marine, Škitace, Škvaranske, Trgeta, Trgetara i Viškovića. ${ }^{1}$ Sva ta naseljena mjesta gra-

1 Službena imena nekih južnih labinskih punktova razlikuju se od onih koja se navode u ovom radu: Koromačno, Ravni, Sveti Lovreč Labinski, Skitača, Skvaranska, no ovdje smo se opredijelili za imenovanje tih naseljenih mjesta onim ojkonimima 
vitiraju gradu Labinu, premda su danas dijelom dviju različitih jedinica lokalne samouprave: Grada Labina (Bartići, Breg, Kapelica i Salakovci) te Općine Raša (preostalih četrnaest mjesta). Najveći se broj ovih punktova nalazi na rubnom, južnom i istočnom području Labinštine, odnosno na uzobalnom prostoru između uvale Prtlog i Raškoga zaljeva, a jedino su Bartići, Breg, Kapelica i Salakovci smješteni više u unutrašnjosti, u neposrednoj blizini Labina (štoviše, Breg i Kapelicu danas možemo smatrati svojevrsnim labinskim predgrađem, a tomu su, zahvaljujući povećanoj izgradnji i urbanizaciji, sve bliže i Salakovci).

Temeljnim povodom za izdvajanje ove poskupine govora iz ukupno 58 labinskih mjesnih govora bio je njihov akcenatski sustav: u svim je tim punktovima u naglasnom sustavu došlo do utrnuća opreka i po kvaliteti i po kvantiteti te je u njima detektiran jednoakcenatski sustav na razini jezika u kojem kao razlikovno obilježje funkcionira samo opreka po naglašenosti. U svim se tim punktovima na razini govora još uvijek razlikuju duljina i kračina naglašena sloga, no oni više nemaju distinktivnu ulogu (Nežić 2013:85-87, 193-194). Uz ovu izoglosu još je nekoliko jezičnih obilježja, ponajprije fonološke, ali i morfološke naravi, bilo presudno za pretpostavku formiranja triju podskupina govora labinskoga tipa. ${ }^{2}$

Govori koji su dijelom južne labinske podskupine bili su predmetom sporadičnih dijalektoloških istraživanja od 1912. godine do sredine prvoga desetljeća 21. stoljeća. Neke su od južnih labinskih govora istraživali Aleksandar Belić, Mieczysław Małecki, Blaž Jurišić, Willem Roelof Vermeer, Janneke Kalsbeek, Silvana Vranić, Sanja Zubčić, Ivana Nežić, ${ }^{3}$ a većina dijalektologa proučavala je ponajprije njihove fonološke karakteristike, dok su one morfološke naravi bile tek rubno zahvaćene i prikazivane. ${ }^{4}$

Vokalski sustav južnih labinskih govora sastoji se od pet vokalskih jedinica $(a, e, i, o, u)$ i slogotvornoga sonanta $r$, a svaka od tih jedinica može

koje uobičajeno rabi mjesno stanovništvo.

2 Više o tome v. u Nežić 2013:373-380.

3 Više o dosadašnjim istraživanjima južnih labinskih govora v. u Nežić 2013:1634.

4 Neke morfološke značajke koje se ponajprije tiču sklonidbe imenica u tim je govorima istražila i opisala S. Vranić (primjerice, gramatičke morfeme G jd. te NAV mn. imenica ženskoga roda, gramatički morfem I jd. imenica ženskoga roda, gramatički morfem G mn. imenica muškoga i srednjeg roda te gramatičke morfeme DLI mn. imenica muškoga i srednjeg roda). V. Vranić 2005:289-316. Prvo sustavnije istraživanje morfološkoga sustava južnih labinskih govora provedeno je za potrebe doktorskoga rada Fonologija i morfologija čakavskih ekavskih govora Labinštine (Nežić 2013). Rezultati toga istraživanja korišteni su i u ovom radu, ali su u međuvremenu dopunjeni novim spoznajama i podatcima s terena. 
biti naglašena i nenaglašena. Svaki dugi vokal $a \mathrm{u}$ ovim je govorima zamijenjen vokalom $o$. Odraz je jata dosljedno ekavski u leksičkim korijenskim i tvorbenim te gramatičkim morfemima, uz minimalan broj ikavizama zabilježenih u korijenu riječi te $u$ tvorbenim morfemima. Na vokalskom je planu zanimljiv i dvojak odraz stražnjega nazala ${ }^{*} Q$ u ovim govorima: ${ }^{*} Q$ je zamijenjen vokalom $u \mathrm{u}$ korijenskim morfemima, $\mathrm{u}$ infinitivnim osnovama glagola s nerelacijskim morfemom no te $\mathrm{u}$ osnovi svršenoga prezenta glagola bit, a u gramatičkim je morfemima A jd. imeničkih riječi ženskoga roda te 3.1 . mn. prezenta glagola na mjestu ${ }^{*} Q$ zabilježen isključivo vokal $o .^{5}$

Od konsonantskih je obilježja govora južne labinske podskupine najuočljiviji cakavizam, značajka koju i sami izvorni govornici ovih govora ističu kao osnovno obilježje svojih zavičajnih idioma. Južni se labinski govori grupiraju u tri skupine s obzirom na provođenje zamjene fonema /čl fonemom /c/: u mjesnim se govorima Brgoda, Crnih, Drenja, Rovnih, Svete Marine i Škvaranske fonem /č/ veoma dobro čuva u svim pozicijama, u mjesnom govoru Trgeta alterniraju primjeri s/č/ i s /c/ (u mlađih se govornika /č/ češće čuva, a kod starijih se češće zamjenjuje s/c/), a u mjesnim govorima Bartića, Brega, Brovinja, Kapelice, Koromašna, Salakovaca, Stanišova, Svetoga Lovreca, Škitace, Trgeta i Viškovića sve generacije izvornih govornika zamjenjuju /č/ s/c/. Generacijska raslojenost cakavizma u južnim labinskim govorima još je snažnije izražena u statusu fonema /s/ $\mathrm{i} / \check{s} /$, odnosno /z/ i /ž/: starije generacije govornika u svim punktovima na mjestu /s/ i /š/ ovjeravaju /ś/, kao i /ź/ na mjestu /z/ i /ž/, dok mlađi govornici dosljedno čuvaju /s/, /š/, /z/ i /ž/ u svim pozicijama. ${ }^{6}$

U ovom se radu donosi prikaz osnovnih značajki morfološkoga sustava južnih labinskih govora. Podatci su prikupljeni terenskim istraživanjem, ${ }^{7}$

5 Za sve je južne labinske govore tipičan jedan zajednički vokalski sustav o kojem više v. u Nežić 2013:117-130, gdje su opisane i ostale vokalske karakteristike ovih govora.

6 S obzirom na veoma složenu situaciju s cakavizmom u južnim su labinskim govorima detektirana dva različita konsonantska sustava: prvi u govorima u kojima je fonem /č/ stabilan dio inventara te drugi u govorima u kojima se /č/ zamjenjuje s /c/, a u svakom od tih dvaju konsonantskih sustava utvrđena su i po dva podsustava: jedan specifičan za govornike starije životne dobi koji poznaju zamjene /s/, /š/ > /ś/ i /z/, $\mid \check{z} />$ /ź/ te drugi za mlađe govornike koji te zamjene ne provode. Više o tome v. u Nežić 2013:151-181, gdje su prikazane i ostale osobitosti konsonantskih sustava govora južne labinske podskupine.

7 Autorica ovoga rada s prvim je terenskim istraživanjima južnih labinskih govora započela 2008. godine, a posljednja su istraživanja provedena krajem 2018. godine. Građa za ovaj rad prikupljana je u izravnom kontaktu s izvornim govornicima dvjema temeljnim metodama: snimanjem zvučnih zapisa ogleda govora (koji su zatim 
a opis morfološkoga sustava uključuje analizu promjenjivih vrsta riječi: deklinaciju imenica, pridjeva, zamjenica i brojeva te konjugaciju glagola. Osim prikaza načina tvorbe pojedinih oblika promjenjivih riječi, donosi se i osvrt na morfonološke alternacije u oblicima u kojima su one zabilježene.

\section{Imenice}

U južnim su labinskim govorima za imenice relevantne četiri gramatičke kategorije: rod (muški, ženski i srednji), broj (jednina i množina), padež (N, G, D, A, V, L, I) te kategorija 'živo'/'neživo' (koja se ponajviše ogleda u A jd. imenica muškoga roda).

$\mathrm{U}$ recentnijim je radovima o morfologiji imenica u čakavskim organskim idiomima uobičajena podjela ove vrste riječi u tri sklonidbene vrste koje nose nazive prema nastavku u G jd.: $a$-, $e$ - te $i$-vrstu (Kalsbeek 1998:64-65; Lukežić-Zubčić 2007:29-39; Vranić 2011:9-10; Nežić 2013:206209), te se ta metodologija slijedi i u ovom radu.

\subsection{Imenice $a$-vrste}

$\mathrm{U}$ imenice $a$-vrste s nastavkom - $a$ u G jd. ubrajaju se u južnim labinskim govorima sve imenice muškoga roda kojima osnova završava konsonantom (uključujući i imenice pluralia tantum poput béci/béči, śúdi), ${ }^{8}$ ali i one u kojih osnova $\mathrm{u} \mathrm{N}$ jd. završava vokalom $-0,-e,-i$ ili $-a$ (u potonju grupu ulaze uglavnom osobna imena i hipokoristici, ali i opće imenice poput bórba, ćáća, Pápa, táta i sl.), te sve imenice srednjega roda, uključujući i zbirne imenice (npr. blógo, grójźe i sl.) i imenice pluralia tantum (kao što su npr. njádra, ústa, vróta). ${ }^{9}$

transkribirani te su iz njih izdvojeni potrebni podatci) i anketiranjem, odnosno primjenom upitnika kojim su se ciljano prikupljali relevantni podatci o morfološkom sustavu ovih punktova.

8 S obzirom na različit status fonema /č/ u govorima koji su bili predmetom istraživanja, u radu se donose ovjereni cakavski i necakavski primjeri koji se međusobno odvajaju kosom crtom. Budući da je najveći broj ispitanika uključenih u ovo istraživanje u svom govoru ostvarivao /ś/ i /ź/ na mjestu /s/ i /š/, odnosno /z/ i /ž/, opredijelili smo se za bilježenje primjera isključivo sa srednjim glasovima kako se tekst ne bi preopteretio navođenjem prevelikoga broja inačica istih leksema, no svakako valja uzeti u obzir da mlađe generacije govornika danas više ne ostvaruju te srednje glasove.

9 Navedeni su primjeri u nominativnom liku, a njihovi su ovjereni genitivni likovi njàdar // njádrah, uś // uśtah, vròt // vrótah. V. i u poglavlju 2. 1. 2. ovoga rada. 


\subsubsection{Muški rod}

\begin{tabular}{|c|c|c|}
\hline & jednina $^{10}$ & množina \\
\hline $\mathrm{N}$ & $-\varnothing,-0,-a,-e,-i$ & $-i / /-i$ \\
\hline G & $-a / /-a$ & $-\varnothing,-i / /-i$ \\
\hline $\mathrm{D}$ & $-u / /-\dot{u}$ & -an, -en // -én, -on // -ón \\
\hline A & $=\mathrm{N}$ jd. ili G jd. & $=\mathrm{N} \mathrm{mn}$ \\
\hline $\mathrm{V}$ & $=\mathrm{N}$ jd., $(-e)$ & $=\mathrm{N}$ mn. \\
\hline $\mathrm{L}$ & $-e / /-\dot{e},(-u / /-\dot{u})$ & $-a h / /-a \dot{h} h^{11}$ \\
\hline $\mathrm{I}$ & -on // -ón, -en // -én & $-i / /-i,-a m i / /-a ́ m i$ \\
\hline
\end{tabular}

Većina imenica muškoga roda $\mathrm{u} \mathrm{N}$ jd. ima nastavak $-\varnothing$. U osobnim se imenima pojavljuju i nastavci -e i -o (potonji je potvrđen i u općim imenicama kunjódo i nóno/núno kojima se izražavaju rodbinski odnosi), dok je nastavak - a potvrđen u općim imenicama bórba, ćáća, Pápa, táta i u osobnim imenima kao što su Mikúla, Źamarija i sl. ${ }^{12}$

Oblik A jd. imenica za 'Živo' jednak je obliku G jd., dok imenice za 'neživo' imaju oblik A jd. jednak onomu N jd., npr. N jd. brát, G jd. bráta, A jd. bráta; odnosno $\mathrm{N}$ jd. kóren, G jd. kórena, A jd. kóren.

Oblik V jd. jednak je obliku N jd. (NV jd. Jośip, múź, otrók, ślovék, tić, Źóran), a nastavak se -e ovjerava jedino u reliktnim petrificiranim zazivima Bóźe i śine (pri čemu je za imenicu śin u izravnu obraćanju zabilježen i oblik V jd. jednak obliku N jd.).

U oblicima Ljd. uobičajen je nastavak -e (brége, bróde, dolcé, kámike, loncé, mire, prỏhe, śnége, ugnjé, vròte, źide), no zabilježeni su i primjeri s novijim nastavkom -u, ponajprije u mlađih govornika, ali i u manjem broju primje-

10 Nastavci zabilježeni za ovoga istraživanja donose se u kurzivu. Dvjema kosim crtama odvajaju se alternacije nastavaka koje se razlikuju svojim prozodijskim obilježjima (naglašeni, odnosno nenaglašeni nastavci), dok se zarezima odvajaju alternativni nastavci, tj. oni koji se razlikuju i svojim glasovnim sastavom, a ne samo prozodijskim obilježjima. U zagradama se donose oni nastavci koji su sporadični i rijetki, poneki zabilježeni u svega po nekoliko primjera.

11 Tijekom ovoga istraživanja nije zabilježen nijedan primjer s nastavkom -eh u L mn. imenica muškoga roda, koji su bilježili raniji istraživači (usp. Vranić 2005:309_ $310,313)$. Štoviše, ispitanici su odbijali ponuđene im oblike s tim nastavkom, opisujući ih kao netipične u južnim labinskim govorima. Nastavak je -ah dobiven ujednačavanjem prema L mn. imenica ženskoga roda (usp. Vranić 2005:310; Nežić 2013:107110, 208-209).

12 Budući da potonje imenice pripadaju $a$-vrsti, one i u G jd. imaju nastavak $-a$, jednako kao i u N jd., stoga su njihovi genitivni likovi zapravo jednaki nominativnima: NG jd. bórba, ćáca, Pápa, táta; Mikùla, Źamarija. 
ra i u stanovništva starije dobi: ${ }^{13}$ na miru, na śvétu. Međutim, za iste su primjere prikupljene i ovjere s nastavkom -e: na mire, na śvéte.

U I jd. nastavak -on uglavnom dolazi na osnove koje završavaju nepalatalnim konsonantom: bráton, bródon, İveton, kumpiron, nüneton, pokrovón, pópelon, pośtolón, śinon, továron, trahtóron, trbühon, vóźon, źajikon; dok nastavak -en najčešće dolazi na osnove koje završavaju palatalnim konsonantom: facolićen, koncén, múźen, océn. Moguć je ipak i nastavak -on na osnovama koje završavaju palatalnim konsonantom: Milijon, mladićon, múźon, noźićon, voźićon; kao i nastavak -en na osnovama koje završavaju nepalatalnim konsonantom: miźólen, púten.

U G mn. u svim su južnim labinskim govorima zabilježeni nastavci -ø i $-i$, pri čemu je nastavak - $i$ dvostruko zastupljeniji od nastavka - $\emptyset$, a veoma često mogu i alternirati $\mathrm{u}$ istom mjesnom govoru, pa čak $\mathrm{i} u$ istom primjeru (npr. bukonić, dinar, krój, susét; brkóni, délovci, jónci, kúsi, miljári, tići, vóli; cigarèt // cigaréti, kilometar // kilómetri, meśéc // meśéci, métar // métri, mladić // mladići, prośóc // prości, tovór // továri). Također, u nekim su istraživanim mjesnim govorima neki primjeri ovjereni s nastavkom -ø, a u drugim su mjesnim govorima isti primjeri zabilježeni isključivo s nastavkom $-i$.

U D mn. zabilježeni su nastavci -en, -on i -an, pri čemu prvi dolazi na osnove koje završavaju palatalnim konsonantom: Gluśićen, Rúzićen, Salákovcen, Śkrpocén, Viśkóvićen; dok drugi dobivaju imenice koje završavaju nepalatalnim konsonantom: bráton, Faragùnon, kóvaron, nükon, śinon, telcón. Nastavak je -an nešto rjeđi (Becićan, Márićan, Viśkóvićan), uveden prema istom obliku padeža imenica ženskoga roda, ${ }^{14}$ te alternira s nastavcima -en i -on ${ }^{15}$ (npr. proścón // proścén).

U I mn. pretežit je nastavak -i, a samo se u četvrtini prikupljenih primjera bilježi i nastavak -ami (uveden prema istom obliku imenica ženskoga roda), ${ }^{16}$ npr. béci, bráti, glóśi, gussti, luźéri, múzi, rukovi, śini, śuśédi; kamjónami, petehámi. U građi prikupljenoj za ovoga istraživanja nastavak -ami alternira s nastavkom - $i$ unutar istoga mjesnoga govora, a često i na primjeru istoga leksema: cepi // cepámi, prèteli // prètelami, prości // proścámi, voli // volámi, vóźi // vóźami.

13 Više o tome v. u Nežić 2013:46-48, 208, 242.

14 V. Finka 1971:46; Vranić 2005:312-313; Nežić 2013:107-110, 243.

15 Isto je u svojem istraživanju južnih labinskih govora ustvrdila i S. Vranić (Vranić 2005:312-313), usp. i Nežić 2013:107-110, 243. I. Lukežić starojezični sinkretizam D mn. i I jd. imenica $a$-vrste muškoga roda ističe kao specifičnost sjevernočakavskih govora (Lukežić 2015:113).

16 V. Vranić 2005:313; Nežić 2013:107, 244. 


\subsubsection{Morfonološke alternacije}

$\mathrm{U}$ dijelu imenica $a$-vrste muškoga roda koje završavaju vokalima $-0,-a$ i -e (najčešće je riječ o osobnim imenima, što domaćega, što stranog podrijetla, ali i općim imenicama kojima se izražavaju rodbinski odnosi, npr. bórba, kunjódo, nóno/núno) moguće je proširivanje osnove sufiksom -et-: G jd. bórbeta, Bóźeta, İveta, nóneta/núneta, Tóneta; D jd. Jócetu, Marjánetu, Mòtetu, Śipetu, Vládetu; A jd. Bránketa, Brüneta, nóneta/núneta; I jd. İveton, nóneton/núneton; $\mathrm{N}$ mn. bórbeti, nóneti/núneti i sl. Zabilježeni su međutim i likovi bez proširka osnove: G jd. bórba, Brùna, Kárla, Kláudija, Márija, Márka, Milija, Rinálda; D jd. kunjódu, Románu; A jd. bórba itd. Općenito se za ovoga istraživanja pokazalo da se spomenute opće imenice gotovo redovito ostvaruju s osnovama proširenim sufiksom -et-, dok je u osobnih imena situacija različita: unutar jednoga se mjesnoga govora, pa čak i u govoru istoga ispitanika, ovjeravaju likovi s proširkom osnove i bez njega. Prikupljeni podatci sugeriraju da su govornici starije životne dobi skloniji ovjeravati likove s prošircima osnove, dok je kod mlađih ispitanika (što može biti i posljedica utjecaja hrvatskoga standardnog jezika) zabilježena tendencija dosljednije uporabe likova bez proširka (osim u nekim tradicionalnim imenima, kao što su primjerice Bépo, Móte, Tóne, Śipe, koja se uvijek ovjeravaju s proširenim osnovama).

U imenica muškoga roda $a$-vrste koje u NA jd. imaju nastavak -ø ispred dočetka osnove i prethodnoga konsonanta umetnut je - $a-$, kao i u dijelu slijedova sonornih konsonanata: bảnjak, bonjk-; bośak, bośk-; céśan/čéśan, ceśn-l čeśn-; céśalj/čéśalj, ceślj-/čeślj-; dolàc, dolc-; kotól, kotl-; lonác, lonc-; métar, metr-; mocák/močák, mośk-; peták, petk-; popór, popr-; prośác, prośc-; śamónj, śamnj-; śtárac, śtorc-; utórak, utork-; tánac, tonc-; ugónj, ugnj-; vétar, vetr-. Nepostojani je - $a$ - umetnut i u sljedovima -nt- i -rt- u dvosložnim imenicama: kánat, kont-; kvárat, kvart-; párat, port-; pónat, pont-; pórat, port-; púnat, punt-.

U južnim su labinskim govorima zabilježene sljedeće izmjene konsonanata izazvane nepostojanim -a-: jednačenje konsonanata po zvučnosti: Rábac, Rapc-; robác, ropc-; źlebàc, źlepc-; ispadanje $t$ ispred c: otác, oc-; śudác, śuc-; mijene izazvane izmjenom šumnika na dočetku zatvorena sloga: $k>h$ (lảkat, laht-; nókat, noht-), č >ś (mocák/močák, mośk-), c >ś (ocát, ośt-), $p>f(K o p a ́ c, K o f c-)$. Obezvučenja su i zamjena $g>h$ potvrđeni u oblicima

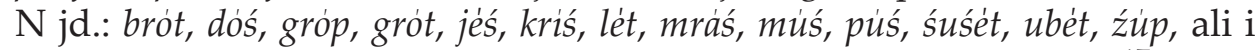

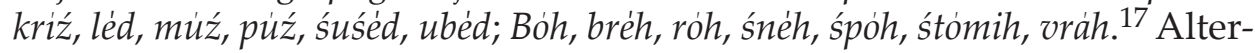

17 U južnim se labinskim govorima provode obezvučenja dočetnih konsonanata te zamjena dočetnoga $g>h$, ali ne dosljedno, jer se većina primjera ovjerava u inačicama s obezvučenim, odnosno zamijenjenim dočetnim konsonantom i bez te promjene. Više v. u Nežić 2013:154-155, 239. 
nacija je $-m>-n$ zabilježena jedino u imenici u značenju 'sram': $\mathrm{N}$ jd. śrón, $\mathrm{G}$ jd. śráma; dok u likovima ostalih imenica takva alternacija nije zabilježena (npr. N jd. Oźóm, G jd. Oźmá, L jd. Oźmé itd.; N jd. gróm, G jd. gróma itd.). Na dočetku suglasničkih skupina -śt i -źd izostavljaju se okluzivi $t$ i $d$ : N jd. gưś: N mn. gúśti, N jd. móś : G jd. móśta, Njd.pr'ś: Gjd. pr'śta, N jd. gróś : G jd. gróźda. Glasovne mijene sibilarizacije i palatalizacije izostaju u očekivanim pozicijama u južnim labinskim govorima. Sibilarizacija je potvrđena jedino u $\mathrm{N}$ mn. imenice $\mathrm{m}$. $\mathrm{r}$. vráh : vráźi, a palatalizacija u $\mathrm{V}$ jd. imenice m. r. Bóh, preciznije, u petrificiranu reliktnu zazivu Bóźe.

2.1.2. Srednji rod

\begin{tabular}{|c|c|c|}
\hline & jednina & množina \\
\hline $\mathrm{N}$ & $-o / /-\dot{o},-e / /-\dot{e},-\varnothing$ & $-a / /-\dot{a}$ \\
\hline $\mathrm{G}$ & $-a / /-\dot{a}$ & $-\varnothing,-a h / /-\dot{a} h$ \\
\hline $\mathrm{D}$ & $-u / /-\dot{u}$ & $-a n$ \\
\hline $\mathrm{A}$ & $=\mathrm{N} \mathrm{jd}$. & $=\mathrm{N} \mathrm{mn}$. \\
\hline $\mathrm{V}$ & $=\mathrm{N} \mathrm{jd}$. & $=\mathrm{N} \mathrm{mn}$. \\
\hline $\mathrm{L}$ & $-e / /-\dot{e},(-u / /-\dot{u})$ & $-a h / /-\dot{a} h$ \\
\hline $\mathrm{I}$ & $-o n / /-\dot{o},-e n / /-\dot{e} n$ & $-a m i / /-a m i,=\mathrm{N} \mathrm{mn},-i$ \\
\hline
\end{tabular}

$\mathrm{U} \mathrm{N}$ jd. nastavak -o imaju uglavnom imenice osnova kojih završava nepalatalnim konsonantom, a nastavak je - $e \mathrm{u}$ imenica koje završavaju palatalnim konsonantom te dijela onih koje završavaju s $c$ ili $r$ (od kojih su neke imale palatalne osnove): móre, śrce, ali i rébro. Nastavak -ø imaju imenice sa sufiksom -en-.

U oblicima L jd. kod starijega je stanovništva uobičajen nastavak -e, no zabilježeni su i primjeri s novijim nastavkom - $u$ ili s alternacijom tih dvaju nastavaka unutar istoga mjesnoga govora, pa čak i u istom leksemu: ${ }^{18}$ blàte, bolovánje, brémene, déle // délu, dné, kolène, léte // létu, méśte, nébe, njoźlé, rámene // rámenu, śele // śelú, śunce, téle, tlè, ugnjiśće // ugnjiśću, ùlje // ùlju, vrémene // vrémenu. $\mathrm{U}$ govoru je mlađega stanovništva nastavak - $u$ danas mnogo češći: va s'rcu, na ugnjiśću, na ùlju, va vrémenu; ali i oni, premda rjeđe, ovjeravaju oblike s nastavkom -e: na délu // na déle, na móru // na móre, va śelu // va śelé.

U I jd. nastavak -on uglavnom dolazi na osnove koje završavaju nepalatalnim konsonantom: blógon, brémenon, gr̀lon, méśon, mlekón, śénon, télon, vinón, vrémenon, źiton; dok nastavak -en najčešće dolazi na osnove koje završavaju palatalnim konsonantom ili $r$ (koji je bio palatalan): grójźen, jójen,

18 V. bilješku 13 ovoga rada. 
liśćen, móren, śrcen, źdróvljen. Iznimno nastavak -en može doći i u imenica s nepalatalnim konsonantom na dočetku osnove: mlekén, śúgen.

U G mn. u svim su južnim labinskim mjesnim govorima zabilježeni nastavci - $\varnothing$ i - $a h$, pri čemu je nastavak - $\varnothing$ dvostruko zastupljeniji od nastavka $-a h,{ }^{19}$ a veoma često mogu i alternirati $\mathrm{u}$ istom mjesnom govoru, pa čak i u istom primjeru (npr. govét, jój, lèt, pér; mestáh, śelàh; njádar // njádrah, úś // uśtah, vròt // vrótah). Također, u nekim su mjesnim govorima neki primjeri ovjereni s nastavkom - $\varnothing$, a u drugim su mjesnim govorima isti primjeri zabilježeni isključivo s nastavkom -ah.

U I mn. kod starijega stanovništva pretežit je nastavak -i, ali bilježi se i nastavak -ami (uveden prema istom obliku imenica ženskoga roda), ${ }^{20}$ npr. govédi, jóji, léti; drévami, uśtami, vrótami. U građi prikupljenoj za ovoga istraživanja nastavak -ami alternira s nastavkom - $i$ unutar istoga mjesnoga govora, a često i na primjeru istoga leksema (npr. jojji // jojami). U mlađih se govornika za I mn. najčešće rabi oblik jednak NA mn.: dréva, joja, uśta, vròta.

\subsubsection{Morfonološke alternacije}

$\mathrm{U}$ nekih imenica $a$-vrste srednjega roda osnova je u svim padežima izuzev u NAV jd. proširena sonantom -n-: NAV jd. ime, préźime/preźime, ${ }^{21}$ vréme; $\mathrm{G} \mathrm{jd}$. imena, vrémena; $\mathrm{L}$ jd. ràmene // rámenu, vrémene // vrémenu; I jd. brèmenon, vrémenon; NAV mn. breména, iména, vrémena. U imenici brémen taj se sufiks analoški proširio i na likove NAV jd. U imenicama njádra i rébro u likovima $\mathrm{G} \mathrm{mn}$. s nastavkom -ø umetnut je $-a-\mathrm{N}$ jd. rébro : $\mathrm{G} \mathrm{mn}$. rébar; $\mathrm{N}$ mn. njádra: G mn. njádar.

\subsection{Imenice $e$-vrste}

Imenice $e$-vrste imaju nastavak - $e$ u G jd. i u tu se vrstu u južnim labinskim govorima uključuju sve imenice ženskoga roda koje u $\mathrm{N}$ jd. završavaju na $-a$ ili $-e$, imenice pluralia tantum (kao što su npr. brgéśi, budónti, śkóri), kao i imenice koje imaju -ø nastavak: hći // hćér (gdje se sufiks -er-iz ostalih padeža mogao proširiti i na oblik $\mathrm{N}$ jd., kakav se ovjerava uglavnom u govoru mlađega stanovništva), kókoś i mát // máter (gdje se sufiks

19 Nastavak je -ah u G mn. imenica srednjega roda rezultat tendencije ujednačavanja prema L mn. istoga roda, koji je pak ujednačen prema obliku L mn. imenica ženskoga roda (Vranić 2005:310); v. i Nežić 2013:107, 243.

20 V. bilješku 16 ovoga rada.

21 U svim južnim labinskim govorima kod ove imenice alterniraju oblici s naglaskom na početnom slogu i oblici s naglaskom na središnjem slogu, s time da mlađi govornici gotovo redovito rabe oblik s naglaskom na početnom slogu, a u starijih je govornika nešto češći oblik s naglaskom na središnjem slogu. 
-er- iz ostalih padeža mogao proširiti i na oblik $\mathrm{N}$ jd., kakav se sporadično ovjerava u govornika svih generacija).

\begin{tabular}{|c|c|c|}
\hline & jednina & množina \\
\hline $\mathrm{N}$ & $a / /-\dot{a},-e,-\varnothing$ & $-i / /-i,-e$ \\
\hline $\mathrm{G}$ & $-i / /-i,-e$ & $-\varnothing,-i / /-i,-a h$ \\
\hline $\mathrm{D}$ & $-e / /-\dot{e}$ & $-a n / /-\dot{-} n$ \\
\hline $\mathrm{A}$ & $-o / /-\dot{o},-\varnothing$ & $=\mathrm{N} \mathrm{mn}$. \\
\hline $\mathrm{V}$ & $=\mathrm{N} \mathrm{jd}$. & $=\mathrm{N} \mathrm{mn}$. \\
\hline $\mathrm{L}$ & $-e / /-\dot{e}$ & $-a h / /-\dot{a} h$ \\
\hline $\mathrm{I}$ & $-o / /-\dot{-},(-\varnothing)$ & $-a m i / /-\dot{a} m i,(-i / /-i)$ \\
\hline
\end{tabular}

Većina imenica ove vrste $\mathrm{u} \mathrm{N}$ jd. ima nastavak - $a$. U osobnim je imenima zabilježen i nastavak -e (npr. Máre, Kóte, Lúce), a nastavak - $\varnothing$ potvrđen je u imenicama hći // hćér, kókoś i màt // màter.

U G jd. pretežit je nastavak - $i$ kao kontinuanta nastavka nekadašnje nepalatalne deklinacije 22 (beśédi, céśti, dáśki, gori, juhi, krávi, nógi, puśtélji, róbi, śkóli, śréći, trovi, vodi, źemlji, źeni), a nastavak je -e potvrđen samo u imenica s dočetkom osnove na c: Brünice, cenice/čenice, Ceróvice, crékvice, gránice, kalánice, Márice, nevéśtice, otrocice/otročice, padélice, prételice, Túnarice, vérice; ali i u takvih je imenica zabilježen nastavak -i: pikuléci, Śkitáci, uźónci.

U imenica koje imaju nastavak $-\varnothing \mathrm{u} \mathrm{N} \mathrm{jd}$. isti je nastavak i u A jd. i I jd., s time da je imenicama hći i mát u A jd. osnova redovito proširena sufiksom -er-.

U NAV mn. pretežit je nastavak - $i$ kao kontinuanta nastavka nekadašnje nepalatalne deklinacije ${ }^{23}$ (bácvi, butégi, hórti, kóźi, krávi, kúći, múhi, rùki, śeśtri, śtáźi, śtrigi, śuśédi, úliki, źvéźdi), a nastavak je -e potvrđen samo u imenica s dočetkom osnove na c: ćikarice, kalánice, kobaśice, kúcice, muśice, ófce/óvce, púpice, róźice, śćrice, śkórice, śmrékovnice, udovice, vijólice, źbúlice, źénskice, źlice; ali i u takvih je imenica zabilježen nastavak -i: bóci, karóci, śtráci, śtrúci, śtupidéci, uźónci.

U G mn. u svim su južnim labinskim mjesnim govorima zabilježeni nastavci $-\varnothing,-i$ i $-a h$, pri čemu je nastavak $-\varnothing$ zastupljen u polovini zabilježenih primjera, a nastavak - $i$ otprilike u petini primjera prikupljenih ovim istraživanjem (bóc, jábuk, kokóś, litar, ovóc, róźic, śúź, úlik, úr, źbic; baráki, dróźgi, nóni; bàlah, butégah, śkólah, śopélah). Sva tri nastavka alterniraju u istim mjesnim govorima, pa čak i sva tri u istom primjeru, npr. beśét // beśédi //

\footnotetext{
22 Više v. u Vranić 2005:289-296; Nežić 2013:101-103, 208-209, 246-247.

23 V. prethodnu bilješku ovoga rada.
} 
beśédah, faméj // faméji // faméjah, krávi // krávah, kripi // kr̀ah, kúć // kúći // kúćah, kurjéri // kurjérah, śmókvi // śmókvah, śkàtul // śkàtuli, vetur // veturi // veturah. Također, u nekim su mjesnim govorima neki primjeri ovjereni s nastavkom $-\varnothing$, a u drugim su mjesnim govorima isti primjeri zabilježeni s nastavcima $-i \mathrm{i} / \mathrm{ili}-a h$.

$\mathrm{U}$ I mn. u svim je istraživanim govorima najčešći nastavak -ami, a u svega je nekoliko primjera zabilježen i nastavak -i (bréntami, créśnjami, kokośámi, kurjérami, nogàmi, ofcámi/ovcámi, rukàmi, śuźami, úlikami; máteri) koji najčešće alternira s nastavkom -ami u istom mjesnom govoru, pa i u istom primjeru (krávi // krávami, śeśtri // śeśtrámi, vetùri // vetúrami, źeni // źenámi). Nastavak se -i najčešće ovjerava u imenica s nastavkom -ø u $\mathrm{N} \mathrm{jd}$., no isto tako i u ostalih imenica.

\subsubsection{Morfonološke alternacije}

Sufiksom -et- proširuju se osnove nekih imenica $e$-vrste ženskoga roda koje završavaju na -e, a riječ je o danas već arhaičnim i slabije frekventnim ženskim osobnim imenima: NV jd. Lúce, Kòte; G jd. Lúceti, Kóteti, DL jd. Lúcete, Kótete, A jd. Lúceto, Kóteto i sl. U nekih je imenica e-vrste ženskoga roda umetnut - $a$ - $\mathrm{u}$ likovima $\mathrm{G}$ mn. s nastavkom -ø: bácva/báčva : bácav/ báčav; créśnja/čréśnja : créśanj/čréśanj; dáśka: daśok; dróźga: droźok; komóśtra: komóśtar; litra : litar; ofcalóvca : ovóc; śmókva : śmókav. Obezvučenje i zamjene dočetnih $g>h$ te $v>f$ zabilježeni su u oblicima G mn.: beśét, droźók, ali i beśéd; bácaf/báčaf, crékaf, śmókaf, ali i bácav/báčav, śmókav; nóh. ${ }^{24}$

\subsection{Imenice $i$-vrste}

U južnim labinskim govorima, kao i u svim sustavima hrvatskoga jezika, $i$-vrsti pripadaju imenice ženskoga roda kojima osnova završava konsonantom, a u G jd. imaju nastavak - $i$.

\begin{tabular}{|c|c|c|}
\hline & jednina & množina \\
\hline $\mathrm{N}$ & $-\varnothing$ & $-i / /-i$ \\
\hline $\mathrm{G}$ & $-i / /-i$ & $-i / /-i,-a h / /-\dot{a} h$ \\
\hline $\mathrm{D}$ & $-e / /-\dot{e},-i$ & $-a n / /-\dot{o} n$ \\
\hline $\mathrm{A}$ & $=\mathrm{N} \mathrm{jd}$. & $=\mathrm{N} \mathrm{mn}$. \\
\hline $\mathrm{V}$ & $-i$ & $=\mathrm{N} \mathrm{mn}$. \\
\hline $\mathrm{L}$ & $-e / /-\dot{e},-i$ & $-a h / /-\dot{a} h$ \\
\hline $\mathrm{I}$ & $-\dot{o},-i$ & $-\dot{a} m i,-i / /-i$ \\
\hline
\end{tabular}

24 V. bilješku 17 ovoga rada. 
U DL jd. stariji govornici češće ovjeravaju nastavak -e, no on katkad alternira s nastavkom - $i$, dok mlađi govornici rabe isključivo oblike s nastavkom - $i$ (nastalim ujednačavanjem prema nastavku G jd.), npr. kroljé // krvi, nóce // nóci, pamećé // pámeti, peće // péći, śoljé // śóli.

U južnim je labinskim govorima u govoru starijega stanovništva u I jd. potvrđen isključivo nastavak -o: kroljó, pamećó, śoljó. Mlađi govornici redovito $\mathrm{u}$ I jd. ovjeravaju oblike s nastavkom - $i$ (dobivenim ujednačavanjem prema G te DL jd.): bóli, krivi, pámeti, śóli.

U G mn. u svim su istraživanim govorima zabilježeni nastavci $-i \mathrm{i}-a h$ koji alterniraju $\mathrm{u}$ istim mjesnim govorima, pa čak $\mathrm{i} u$ istom primjeru, npr. peći // pećáh, śténi // śtenàh, vrósti // vrśtah.

U I mn. kod starijih je govornika najčešći nastavak -ami, npr. kośćámi, pećámi, śtenámi. Rijetko se u starijih govornika bilježe i primjeri s nastavkom -i. Mlađi pak govornici rijetko ovjeravaju primjere s nastavkom -ami, a mnogo češće one s nastavkom - $i$ (uvedenim ujednačavanjem prema NA, pa i prema $\mathrm{G}$ mn.), npr. kóśti, péći, śteni.

\subsubsection{Morfonološke alternacije}

U dijelu imenica $i$-vrste ženskoga roda kojima osnove završavaju na $-v-,-l-,-t-$, odnosno -śt-, pojavljuje se u L jd. ispred nastavaka -e, odnosno u I jd. ispred nastavka -o alternacija s -vlj-, -lj-, -ć- te -ść-: L jd. krvljé, mládośće, śoljé; I jd. kroljó, pamećó, śoljó. Na dočetku suglasničkih skupina -śt i -źd izostavljaju se okluzivi $t$ i $d$ : $\mathrm{N}$ jd. koriś : G jd. koriśti, $\mathrm{N}$ jd. máś : G jd. máśti, $\mathrm{N}$ jd. mládoś : G jd. mládośti, $\mathrm{N} \mathrm{jd}$. śtároś : $\mathrm{G}$ jd. śtárośti.

2.4. Primjeri sklonidbe nekih imenica koje odudaraju od navedenih sklonidbenih vrsta

NAV decà, G decéh // decé, ${ }^{25} \mathrm{D}$ decón, L decéh, I decámi

NA jd. dón, G jd. dnéva, L jd. dnéve, I jd. dnévon, NA mn. dnévi // dni,26 $\mathrm{G} \mathrm{mn}$. dón // dnévi, ${ }^{27} \mathrm{~L} \mathrm{mn}$. dnévah, I mn. dnévami

NV jd. hći // hćér, ${ }^{28}$ G jd. hćéri, DL jd. hćeré, AI jd. hćér, NAV mn. hćéri,

25 U južnim labinskim govorima češće se ovjerava oblik s nastavkom -eh. Međutim, i unutar istoga mjesnoga govora, pa čak i u govoru istoga obavjesnika, zabilježena je paralelna uporaba obaju nastavaka.

26 U svim istraživanim mjesnim govorima mogu alternirati likovi s kratkom i oni s proširenom osnovom.

27 Likovi s nastavkom -ø u svim su govorima zabilježeni u sintagmama kojima se definira određeno vremensko razdoblje (léto dón, méśec dòn), a inače su češći likovi s nastavkom $-i$.

28 Lik sa sufiksom -er- jednak onomu akuzativnomu ovjeren je u govoru mlađih ispitanika. 
D mn. hćéran, L mn. hćérah, I mn. hćérami // hćéri ${ }^{29}$

$\mathrm{NV}$ jd. mát // màter, ${ }^{30} \mathrm{G}$ jd. máteri, DL jd. mátere, AI jd. máter, NAV mn. máteri, D mn. máteran, L mn. máterah, I mn. máterami // máteri ${ }^{31}$

NAV jd. óko, G jd. óka, D jd. óku, L jd. óke, I jd. ókon, NAV mn. óce/óče, G mn. ocij/očij // ocijah/očijah, L mn. ocijah/očijah, I mn. ocijami/očijami // óce/óče ${ }^{32}$

NAV jd. ùho, G jd. ùha // uhà,, ${ }^{33} \mathrm{Ljd}$. whè, I jd. ùhon // uhón, ${ }^{34} \mathrm{NAV}$ mn. úśi // usée, ${ }^{35} \mathrm{G}$ mn. uśij // uśijah, L mn. uśijah // uśeh, I mn. uśijami // uśé ${ }^{36}$

NAI jd. śtvór, G jd. śtvóri, L jd. śtvóre, NA mn. śtvóri // śtvóra, ${ }^{37} \mathrm{G}$ mn. śtvór // śtvórah // śtvóri, ${ }^{38} \mathrm{~L} \mathrm{mn}$. śtvórah, I mn. śtvórami // śtvóri // śtvóra ${ }^{39}$

Imenica ślovék u jednini se sklanja kao imenica m. r. a-vrste, a u množini se rabe sljedeći likovi: NGAV mn. ljúdi, D mn. ljúden, I mn. ljüdemi // ljüdi. ${ }^{40}$

Imenica bórba sklanja se kao imenica m. r. $a$-vrste kad se rabi samostalno, a kad je u funkciji apozicije, indeklinabilna je: D jd. bórba Mótetu, I jd. bórba Móteton i sl.

29 U svim mjesnim govorima obavjesnici ovjeravaju likove s nastavkom -ami i likove s nastavkom $-i$.

30 U govoru starijega stanovništva u svim su mjesnim govorima zabilježeni likovi bez sufiksa -er-, ali i oni s analoškim oblikom ujednačeni s onim akuzativnim (pri čemu se likovi bez sufiksa rabe mnogo češće). Mlađi govornici rijetko upotrebljavaju ovaj leksem i on za njih ima arhaičan prizvuk te umjesto njega rabe leksem máma.

31 V. bilješku 29 ovoga rada.

32 Mlađe stanovništvo gotovo redovito u I mn. ovjerava lik jednak onomu NAV mn., a isto je zabilježeno i kod starijih govornika, premda je kod njih ipak češći lik s nastavkom -ami.

33 Stariji govornici češće ovjeravaju lik s naglaskom na dočetnom slogu, no i kod njih se sve više rabi lik s naglaskom na početnom slogu koji je uobičajen u mlađega stanovništva.

34 V. prethodnu bilješku ovoga rada.

35 U svim južnim labinskim govorima zabilježena je alternacija likova s nastavkom -i, odnosno -e u NA mn., no likovi s nastavkom - $i$ ipak su mnogo češći.

36 Kod govornika koji u NA mn. ovjeravaju lik úśe zabilježen je lik I mn. jednak onomu NA mn., dok su kod govornika kod kojih je u NA mn. potvrđen lik uśi u I mn. ovjereni likovi s nastavkom -ami.

37 U svim je istraživanim govorima zabilježena alternacija likova s nastavkom -i, odnosno - $a$ u NA mn., no likovi s nastavkom - $i$ ipak su mnogo češći.

38 Likovi s nastavcima -, , - i i -ah u G mn. alterniraju u svim govorima južne labinske podskupine.

39 Kod govornika koji u NA mn. ovjeravaju lik śtvóri zabilježen je lik I mn. jednak onomu NA mn., dok kod govornika kod kojih je u NA mn. potvrđen lik śtvóra alterniraju u I mn. likovi s nastavcima -ami i likovi jednaki onima NA mn.

40 U svim mjesnim govorima obavjesnici ovjeravaju likove s nastavkom -emi i likove s nastavkom - $i$. 
Starije stanovništvo rabi imenicu tète, a kod mlađih je govornika uobičajen lik téta (koji se danas sve češće može čuti i u govoru starijega stanovništva). Ta se imenica sklanja kao imenica ž. r. $e$-vrste kad se rabi samostalno, a kad je u funkciji apozicije, indeklinabilna je: G jd. téta Mariji // téte Mariji, DL jd. téta Marije // téte Marije, A jd. téta Marijo // téte Marijo i sl.

Imenice čine 'kino' i kafé u južnim su labinskim govorima indeklinabilne.

\section{Pridjevi}

U južnim su labinskim govorima za pridjeve relevantne gramatičke kategorije roda (muški, srednji i ženski), broja (jednina i množina), padeža i kategorija 'živo'/'neživo' u jednini muškoga roda. Opisni i gradivni pridjevi te glagolski pridjevi trpni iskazuju i gramatičku kategoriju određenosti u NV (te A za 'neživo'), a isto je zabilježeno i u nekim popriloženim konstrukcijama. Ta se kategorija neodređeno : određeno izražava isključivo nastavcima - $\varnothing$, odnosno - $i$ u spomenutim padežima, dok u ostalim oblicima nije zabilježena promjena u naglasku pa se na temelju toga ne može zaključivati o određenosti ili neodređenosti pridjeva.

U južnim se labinskim govorima dio pridjeva pojavljuje u imeničkoj funkciji: Crkvéno, Dóbro, Lovrecéva/Lovrečéva, Petróva, Télovo/Télova, komúśka, mlóda, mlódi, móla, móli, muśsi, śirota, śkuro, vecérnja/večérnja, źénśka.

$\mathrm{U}$ istraživanim se govorima ne sklanjaju pridjevi stranoga podrijetla čeléśte ‘koji je boje čistoga neba, plav', léśo 'kuhan', róśto 'pečen', róźa 'ružičast'. Za razliku od prethodnih, pridjev fúrbo, furba 'lukav, prepreden', koji je također stranoga podrijetla, iskazuje kategoriju roda, ali je izuzev toga indeklinabilan.

\subsection{Određeni lik}

Likovi pozitiva pridjeva određenoga lika te oblika komparativa i superlativa tvore se sljedećim nastavcima:

\begin{tabular}{|c|c|c|c|c|c|c|}
\hline & m. r. jd. & s. r. jd. & ž. r. jd. & m. r. mn. & s. r. mn. & ž. r. mn. \\
\hline $\mathrm{N}$ & $-i / /-i$ & $-o / /-\dot{o},-e$ & $-a / /-\dot{a}$ & $-i / /-i$ & $-e /-\dot{e},-a /-\dot{a}^{41}$ & $-e /-\dot{e}$ \\
\hline $\mathrm{G}$ & \multicolumn{2}{|c|}{$-e g a / /-\dot{g} g a$} & $-e / /-\dot{e}$ & \multicolumn{4}{|c|}{$-e h / /-\dot{e} h$} \\
\hline
\end{tabular}

41 Stariji govornici u N mn. s. r. gotovo redovito ovjeravaju nastavke jednake onima N mn. ž. r., a mlađi govornici takve sinkretizirane oblike rabe izrazito rijetko ili ih uopće ne rabe - kod njih su zabilježeni, vrlo vjerojatno pod utjecajem hrvatskoga standardnog jezika, posebni nastavci za srednji rod $-a /-\dot{a}$. 


\begin{tabular}{|c|c|c|c|c|c|c|}
\hline $\mathrm{D}$ & \multicolumn{2}{|c|}{-етu // -ému } & $-e / /-\dot{e}$ & \multicolumn{3}{|c|}{-en // -én } \\
\hline A & $=\mathrm{N} / \mathrm{G}$ & $=\mathrm{N}$ & $-0 / /-\dot{o}$ & $=\mathrm{N}$ & $=\mathrm{N}$ & $=\mathrm{N}$ \\
\hline $\mathrm{V}$ & \multicolumn{2}{|c|}{$=\mathrm{N}$} & $=\mathrm{N}$ & \multicolumn{3}{|c|}{$=\mathrm{N}$} \\
\hline $\mathrm{L}$ & \multicolumn{2}{|c|}{-en // -én } & $-e / /-\dot{e}$ & \multicolumn{3}{|c|}{-eh // -éh } \\
\hline I & \multicolumn{2}{|c|}{-en // -én } & $-o$ // - & \multicolumn{3}{|c|}{-emi // -émi } \\
\hline
\end{tabular}

Jednaki nastavci kao za određene pridjeve s naglaskom na vokalu osnove rabe se i u oblicima komparativa, superlativa, rednih brojeva i glagolskih pridjeva trpnih, kao i u nekih pridjevskih neodređenih zamjenica, npr. zamjenica néki, śáki, upitne zamjenice $k i$, posvojne zamjenice njéni te složenih pokaznih zamjenica (o)vaiśti, taiśti, onaiśti.

Samo određeni nastavci zabilježeni su i u odnosnih (relativnih) pridjeva koji završavaju na -śk-i, -nj-i, -aśnj-i i -ji: bladónjśki, labinjónśki, śkitacónśki/ śkitačonśki; dolénji, gorénji, śakidónji; danáśnji; bojźi, tủji, vrájźi, kao i u nekih drugih pridjeva: domóci, láhki, lévi, mići, móli, próvi, śori, véli.

Pojava je naglašenih nastavaka zabilježena u vrlo malom broju primjera: dobró, G dobréga; mokró, G mokréga; tepló, G tepléga.

U NA jd. s. r. nastavak se -o dodaje osnovama s nepalatalnim dočetnim konsonantom, a nastavak - $e$ osnovama s palatalnim dočetnim konsonantom (jednako je i u komparativima i superlativima s. r.): dúgo, láhko, nóvo, tepló, domóće, grije, trje, nájlepśe, nájmanje, ali zabilježeni su i primjeri u kojima nastavak -o dolazi na osnove s palatalnim dočetkom, često čak i s alternacijom nastavaka -e i -o u istom mjesnom govoru: ${ }^{42}$ liśo, domóćo (uz domóće), nájlepśso (uz nájlepśe), nájmanjo (uz nájmanje).

Oblik A jd. m. r. za značenje 'živo' jednak je obliku G, a za značenje ‘neživo' jednak je obliku N.

\subsection{Neodređeni lik}

\begin{tabular}{|c|c|c|c|c|c|}
\hline N jd. m. r. & N jd. s. r. & N jd. ž. r. & N mn. m. r. & N mn. s. r. & N mn. ž. r. \\
\hline$-\varnothing$ & $-o,-e$ & $-a / /-\dot{a}$ & $-i$ & $-e / /-a^{43}$ & $-e$ \\
\hline
\end{tabular}

42 Starije stanovništvo češće ovjerava oblike s nepalatalnim nastavkom -o, koji je, prema podatcima prikupljenima za ovoga istraživanja, očito u južnim labinskim govorima bio generaliziran u srednjem rodu zamjeničko-pridjevske sklonidbe. Kod mlađih je govornika danas već frekventnije stanje u kojem se nastavak -e dodaje osnovama s dočetnim palatalnim konsonantom, a nastavak se -o dodaje osnovama s dočetnim nepalatalnim konsonantom. Međutim, i od mlađega su stanovništva dobivene ovjere nekadašnjega prevladavajućeg nastavka -o i kod osnova s palatalnim dočetnim konsonantom.

43 V. bilješku 41 ovoga rada. 
Morfološka je razlika neodređenih pridjeva od određenih vidljiva jedino u $\mathrm{N}$ jd. m. r., a jednako je i u glagolskim pridjevima trpnima: pecén/ pečèn : pecéni/pečéni, śtorén : śtoréni, źgorén : źgoréni. U ostalim je oblicima teško utvrditi je li lik pridjeva određen ili neodređen jer nema promjene naglaska.

Relikti su sklonidbe neodređenih pridjeva ovjereni u petrificiranim oblicima u genitivnim likovima, npr. od mála 'odnedavno', do śita.

Samo neodređeni oblik u N(A) jd. m. r. s nastavkom -ø i određeni oblik u ostalim padežima imaju i posvojne zamjenice mój, tvój, náś, váś, njegóf, njihof itd., posvojno-povratna zamjenica śvój, pokazne zamjenice vá, tá, oná, (o)vakóf, takóf, onakóf, upitne pridjevske zamjenice cegóf/čegóf, kakóf te neodređene zamjenice nécegof/néčegof, nicegof/ničegof, śácegoflśáčegof, nékokof, nikokof, śákokof, a tako je i u posvojnih pridjeva sa sufiksima -ov,-in: brátov, Mótetov, nónetov/núnetov, Tónetov, Lúcetin, mámin, máterin, te nekih pridjeva sa sufiksima -iv, odnosno -if: boleźljiv/boležljif, krmeźljiv/krmeźljif, kao i u nekih drugih pridjeva: bóś, dóbar, mìt, śit, źálośan, źejón.

U južnim se labinskim govorima značenje posvojnosti, kao i posvojnost $\mathrm{u}$ širem smislu (povezana uz odnosne i gradivne pridjeve) najčešće izražava sintagmom od + imenica u G: od dréva, od śtaklà, od kokośi, od krávi. Nešto se češće rabe jedino posvojni pridjevi kojima se iskazuju porodični odnosi: mámin, máterin, nónetov/nùnetov, nónin/nùnin, ali i od máteri, od nóni/od núni, a isključivo se rabe sintagme (a ne i posvojni pridjevi) od bráta, od múźa, od ocá, od śeśtri, od źeni. Posvojni se pridjevi rabe za izražavanje pripadnosti porodičnoj lozi: Ema Kólcova, Làura Benjaminova, Lina Péretova, Lúce Śipetova, Mário Lemeśicin, Marija Brgócova, Nita Móricina, Palmira Boźórova, Pávica Piśkalova, Ślávica Franićova.

\subsection{Komparativ i superlativ}

Komparativ se tvori od osnove pozitiva i sufikasa -ś-, -j- ili -éj-.

Sufiks je -ś- u južnim labinskim govorima rijedak u tvorbi komparativa: lépśi, mékśi, lákśi (uz láglji).

Sufiks -j- najčešće dolazi uz jednosložne osnove pozitiva te uz osnove sa sufiksima -ok- i-ak- koji se izostavljaju u komparativu: grúblji, gúśći, triji; dủblji, kráći, làglji (uz lákśi), réji, śiri, tánji, téźi, uźi, viśi (uz viśokéji).

U istraživanim se govorima komparativ najčešće tvori sufiksom -éj-koji dolazi uz jednosložne i višesložne osnove pozitiva koje završavaju konsonantom, kao i uz osnove koje završavaju skupinom konsonanata u oblicima bez nepostojanoga -a-: beléji, crnéji/črnéji, novéji, punéji, ranéji, ślabéji, 
śtarèji, śkurèji, źdravéji; bogatèji, pośtenéji, veśelèji, viśokéji (uz viśi), źednèji; blatnéji, hladnéji, kaśnéji, mirnéji, śrećnéji, śvetléji, tepléji.

$\mathrm{Na}$ osnovu se komparativa dodaju sljedeći nastavci: $-i \mathrm{u}$ jd. m. r., - $e$ ili -o u jd. s. r., ${ }^{44}-a$ u jd. ž. r., $-i$ u mn. m. r., -e ili - $a$ u mn. s. $r^{45}$ te $-e$ u mn. ž. r.

Superlativ se dobiva tako što se komparativu predmeće prefiks naj-: nájbolji, nájdeblji, nájdebuléji, nájfortéji, nájlepśi, najmläji, nájpametnéji, najráje, nájślaji, nájśrećnéji, nájśtaréji, nájvaźnéje. Prefiks se naj- predmeće i nekim pridjevima koji, formalno gledajući, nisu komparativi, ali mogu imati komparativno značenje: nájdolénji, nájgorénji, nájprvo.

\subsection{Komparativi s različitim osnovama}

U komparativu nekih pridjeva pojavljuju se supletivne osnove: dóbar : bólji, móli (ali i mići) : mánji, véli : véći, póredan : hủji (ali i porednéji).

\subsection{Morfonološke mijene u pridjevima}

Nepostojani je - $a$ - zabilježen u osnovama nekih neodređenih pridjeva u N i A jd. m. r. za 'neživo' koje završavaju skupinom konsonanata i imaju nastavak -ø: blàtan: blàtna, dóbar: dobrá, hlodan: hlódno, krépak: krépko, krótak: kròtka, lácan/láčan: láśna, lúśtar : lúśtra, mékak: méhka, miran: mirna, mókar : mokrá, niźak : niśka, prónat : prónta, próźan : próźno, śládak : ślátka, śréćan: śréćna, śpórak: śpórka, tépal : tepló, téźak : téśka, trudòn: trudná, źálośan: źálośna itd.; ali i źvélt : źvélta.

U nekim pridjevima dolazi do jednačenja konsonanata nejednake zvučnosti: fréźak: fréśka, niźak: niśka, rédak: rètka, ślàdak: ślátka, téźak: téśka, uźak: úśka. U dijelu primjera dolazi do izmjene konsonanata uslijed slabljenja napetosti šumnika u zatvorenu slogu: lácan/láčan : láśna, mékak: méhka, múcan/múčan: múśna, źúkak: źủhka, a dočetni okluziv $t$ izostavlja se u konsonantskoj skupini -śt na dočetku neodređenih pridjeva u N i A jd. m. r. za 'neživo': ciś/čiś : ciśta /čiśta, furéś : furéśta, góbaś : góbaśta, grés : gréśta, túś : túśta.

U NA jd. m. r. za 'neživo' neodređenoga pridjeva mr̀t izostaje dočetni $v$ koji se bilježi u oblicima svih drugih padeža (kao i rodova i brojeva): mritva, mŕtvi. Dočetni zvučni konsonanti osnove u NA jd. m. r. za 'neživo' neodređenih pridjeva mogu biti zamijenjeni svojim zvučnim parnjacima, kao što se na dočetku istih padeža takvih pridjeva mogu događati i zamjene dočetnih $g>h$ te $v>f$, ali te izmjene mogu i izostati: mlòt : mlodá, śláp : ślába; dróh: drogà, dùh : dùga; boleźljiff: boleźljiva, krif: kriva, źdróf :źdráva; ali i mlód, śláb, boleźljiv, kriv, źdróv.

44 V. bilješku 42 ovoga rada.

45 V. bilješku 41 ovoga rada. 
U komparativima se nekih pridjeva izostavljaju sufiksi -ok- i -(a)k-, a takvi se komparativi najčešće tvore sufiksom -j- (uz-éj-): dubók: dub-u dúblji, krótak: krat-u kráći, láhko : lag- u láglji (ali i lákśi), rétko: red-u réji, śládak: ślad- u śláji, śirók: śir- u śiri, tának: tan- u tánji, téźak: teź- u téźi, uźak: uź- u uźi, viśók: viś- u viśi (ali i viśokéji). U komparativima su pridjeva zabilježene i sljedeće mijene dočetnih konsonanata osnove: $t>c$ : kráći, gúśći, plići; $d>j:$ gr̀ji, mlàji, réji, śláji, trìji; $g>z$ z: dráźi, dúżi; $n>$ ń: tánji.

\section{Zamjenice ${ }^{46}$}

\subsection{Osobne zamjenice i povratna zamjenica}

Osobne se zamjenice za 1. i 2. lice mijenjaju prema prvoj zamjeničkoj sklonidbi. ${ }^{47}$ One imaju jedninu i množinu, ali nemaju kategorije roda, kategoriju 'određenosti', odnosno 'neodređenosti', kao ni kategoriju 'Živo'/'neživo'. Jednina i množina povratne zamjenice iskazuje se istim likovima. Zamjenica za 2. lice pojavljuje se u svih sedam padeža, dok zamjenica za 1. 1. nema vokativa, kao ni povratna zamjenica, koja pak nema ni nominativa. U G, D i A sve te zamjenice imaju i nenaglašene oblike.

\begin{tabular}{|c|c|c|c|c|c|}
\hline & $1.1 . \mathrm{jd}$. & $2.1 . \mathrm{jd}$. & $1.1 . \mathrm{mn}$. & $2.1 . \mathrm{mn}$. & povratna \\
\hline $\mathrm{N}$ & $\mathrm{ja}$ & $t i$ & mi & vi & - \\
\hline $\mathrm{G}$ & mené, me & tebé, te & náś, naś & váś, vaśs & śebé, śe \\
\hline $\mathrm{D}$ & mené, mi & tebé, $t i$ & nón, nan & vón, van & śebé, śe \\
\hline $\mathrm{A}$ & mené, me & tebé, te & náś, naś & váś, vaś & śebé, śe \\
\hline $\mathrm{L}$ & mené & tebé & námi & vámi & śebé \\
\hline $\mathrm{I}$ & $\begin{array}{c}\text { mánon // } \\
\text { námi }\end{array}$ & tóbon & námi & vámi & śóbon \\
\hline
\end{tabular}

46 U prikazu se zamjenica u južnim labinskim govorima slijedi metodologija primijenjena u raspravi S. Vranić o morfologiji govora sjeverozapadnoga makrosustava na otoku Pagu (Vranić 2011:99-108; v. i Nežić 2013:250-267).

47 I. Lukežić u radovima o zamjenicama u čakavskom narječju (Lukežić 2000, Lukežić 2001) govori o trima zamjeničkim sklonidbama. Ta se podjela zamjeničkih sklonidbi primjenjuje $u$ recentnoj hrvatskoj čakavološkoj literaturi (usp. Lukežić-Zubčić 2007:39-48; Vranić 2011:99-108), pri čemu se druga zamjenička sklonidbena vrsta naziva i zamjeničko-pridjevskom sklonidbom (jer se prema njoj sklanja dio zamjenica, ali i određeni pridjevi; usp. Lukežić-Zubčić 2007:40-48; Vranić 2011:102).

48 Oblik je zabilježen u govorima Brgoda, Brovinja, Koromašna, Stanišova, Svetoga Lovreca, Škitace, Viškovića i Trgetara. Vjerojatno je postojao metatizirani lik namon, potvrđen i u mnogim drugim čakavskim govorima (usp. Lukežić 2000:100), a u spomenutim se govorima on zbog sličnosti glasovnoga sastava stopio s oblikom za isti padež zamjenice za 1. 1. množine. V. i Nežić 2013:252-253. 
Za zamjenice za 3. lice relevantne su kategorije roda i broja, a imaju šest padeža. Mijenjaju se prema drugoj zamjeničkoj sklonidbi. U N jd. m. r. nekih zamjenica nastavkom se izražava kategorija 'određenosti', a nastavkom A jd. m. r. kategorija 'živo', odnosno 'neživo'. Nepostojanje alomorfa u nastavcima GDAL jd. muškoga i srednjeg roda te postojanje naglašenih i nenaglašenih oblika u GDA jd. i mn. značajke su kojima se osobne zamjenice za 3. lice razlikuju od ostalih zamjenica koje pripadaju istoj sklonidbi.

\begin{tabular}{|c|c|c|c|c|c|c|}
\hline & m. r. jd. & s. r. jd. & ž. r. jd. & m.r.mn. & s. r. mn. & ž. r. mn. \\
\hline $\mathrm{N}$ & ón & onó & oná & oni & $\begin{array}{l}\text { oné // } \\
\text { onda }\end{array}$ & oné \\
\hline G & \multicolumn{2}{|c|}{ njegá, ga } & $n j e, j e$ & \multicolumn{3}{|c|}{ njih, hi / gi (ih $)^{50}$} \\
\hline $\mathrm{D}$ & \multicolumn{2}{|c|}{ пјетú, mu } & $n j e ́, j e$ & \multicolumn{3}{|c|}{ njimi // njin, ${ }^{51}$ in } \\
\hline A & \multicolumn{2}{|c|}{ njegá, njega, ga } & $\begin{array}{l}\text { njo, njo, } \\
\text { jo // je }\end{array}$ & \multicolumn{3}{|c|}{ njih, hi / gi (ih), ${ }^{52}$ njeh } \\
\hline $\mathrm{L}$ & \multicolumn{2}{|c|}{ nјетù // njén ${ }^{53}$} & njé & \multicolumn{3}{|c|}{ njimi } \\
\hline I & \multicolumn{2}{|c|}{ njin } & njó & \multicolumn{3}{|c|}{ njimi } \\
\hline
\end{tabular}

U A jd. silina s naglašena vokala zamjenica ón, onó i oná prelazi na proklitiku: nó njega, pó njega, źó njega; nó njo, pó njo, źó njo.

U A mn. zamjenica oni, oné // oná i oné zabilježen je posebni klitički oblik njeh koji se rabi kad silina prelazi na proklitiku: nó njeh, pó njeh, źo njeh.

4.2. Upitne i odnosne zamjenice za značenje 'živo' ( $k i$ ) i 'neživo' (cál čá // có/čó) i njima tvorene zamjenice

Upitne se i odnosne zamjenice za 'živo' ki 'tko' i 'neživo' cá/čá // có/čó 'što' sklanjaju prema trećoj zamjeničkoj sklonidbi, prema kojoj se mijenjaju i od njih izvedene složene neodređene zamjenice.

\begin{tabular}{|c|c|c|}
\hline $\mathrm{N}$ & $k i$ & $c \dot{c} / \check{c} a \dot{a}, c o / c ̌ c o ́$ \\
\hline G & kéga & cegá/čegá \\
\hline $\mathrm{D}$ & kému & cému/čému \\
\hline A & kéga & $c \dot{a} / c \breve{c} a, c o l c ̌ c o$ \\
\hline
\end{tabular}

49 V. bilješku 41 ovoga rada.

50 U južnim se labinskim govorima najčešće bilježe metatizirani likovi hi, odnosno gi, a polazišni lik ih ovjerava se sporadično.

51 Alternacija tih dvaju likova s različitim nastavcima zabilježena je u svim istraživanim govorima.

52 V. bilješku 50 ovoga rada.

53 V. bilješku 51 ovoga rada. 


\begin{tabular}{|c|c|c|}
\hline $\mathrm{L}$ & kému & cén/čén \\
\hline I & kén & cén/čén \\
\hline
\end{tabular}

Zamjenica ki u južnim je labinskim govorima zabilježena i u neodređenom, egzistencijalnom i distributivnom značenju: ${ }^{54}$ Móreś śé právit ku te ki pita.; Néka déla kakó ki će.; Ki vóli, móre śtàvit i củkara.; Nùtre śe hódi kakó ki pride.

Zamjenica za 'neživo' pojavljuje se u oblicima cá, odnosno čáa, a u tzv. egzistencijalnom značenju 'išta, bilo što', odnosno u neodređenom značenju, zabilježena je u oblicima có, odnosno čó: Béci je biló, a ni biló có kupit. A śadà ni ni béci ni có kupit!; Jùtro ràno, na cetiri i có, véć śi bi támo i śi kośi.; Mi béśemo có pojále ku je biló.; Śon miślila da je móbitel źelà, da gré čó govorit.; Jà śon vájka bi málo dálje i promátra ljúdi, kú śon rivó čó videt.; Da je có cú da je púknulo, ali ni nic.; Dókle je takó, dók śe có ne kambjó.

U funkciji veznika u zavisnosloženoj rečenici zamjenica cá/čá može se odnositi i na 'živo': ...od móje téti Luceti, cá je od Milána źená bilả...; Pókle je bilà ová Śkitacónka cá je bilá oźénjena źa Márija.; Ánke jená od Br̉goda cá je délala támo...; Jóś je oná Tóni cá déla Koromáśnen.

Zamjenica cálč́a u vezi s prijedlozima po i źa ovjerena je u A i u kraćoj inačici $c / c ̌$ (koja može biti zamijenjena sa ś uslijed slabljenja napetosti šumnika na dočetku zatvorena sloga): Źóc śi tó śtóri?; Źós śe źvólo krpánica?; Źóś me pitaś?; Ti znoś źoś je tó takó biló.; Ne źnón źóc.; Źóc śo délali śkúpa?; Póc śte śli tàmo?

U južnim su labinskim govorima zabilježene sljedeće neodređene zamjenice za 'neživo' izvedene iz zamjenice cá/čá: NA nic/nič/niśs, G nicegal ničega, D nicemu/ničemu, LI niceren/ničeren; NA néśto, ${ }^{55} \mathrm{G}$ nécega/néčega, D nécemu/néčemu, LI necéren/néčeren; GA śácega/śăčega, D śácemu/śáčemu,

$54 \quad$ Usp. Houtzagers 1985:98-99; Kalsbeek 1998:165-166; Vranić 2011:101. Neodređeno se i egzistencijalno značenje tih zamjenica uglavnom pojavljuje u zanijekanim, pogodbenim ili upitnim rečenicama, a distributivno u kombinaciji s upitnim riječima koje imaju "distributivno" značenje, odnosno s drugim upitnim zamjenicama ili upitnim prijedlogom.

55 Prisutnost likova nešto, ništo, pošto, zašto u čakavskim idioma M. Moguš drži etapom vlastita čakavskog razvoja, a ne štokavskim elementima. U čakavskim se idiomima naime zamjenica ča u prijedložnoj vezi može upotrebljavati i u krnjem liku $\check{c}$ koji se zamjenjuje sa š zbog prirode čakavskoga sloga, a ponegdje se tako dobivenomu čakavskom obliku dodaje još i navezak to (Moguš 1982:4). I. Lukežić piše da je neodređena složena zamjenica nešto nastala od upitno-odnosne zamjenice za 'neživo' i oblika nominativa pokazne zamjenice srednjega roda u jednini to (Lukežić 2001:32). Ista autorica drži tu zamjenicu novijom pojavom u čakavskim govorima te je objašnjava kao rezultat jezičnih dodira sa štokavskim idiomima (Lukežić 2001:34). 
LI śáceren/śáčeren; bilo cá/billo čá; ca gót/ča gót. ${ }^{56}$

U istraživanim su govorima ovjerene sljedeće neodređene zamjenice za značenje 'živo' izvedene iz zamjenice ki: niki, GA nikega, DL nikemu, I niken; néki, GA nékega, DL nékemu, I néken; śáki, GA śákega, DL śákemu, I śáken; bilo ki; ki gót; málo ki.

4.3. Upitno-odnosna pridjevska zamjenica $k i, k a ́$, kó i njome tvorene zamjenice

Te se zamjenice mijenjaju prema drugoj zamjeničkoj sklonidbi.

\begin{tabular}{|c|c|c|c|c|c|c|}
\hline & m. r. jd. & s. r. jd. & ž. r. jd. & m.r. mn. & s. r. mn. & ž. r. mn. \\
\hline $\mathrm{N}$ & $k i$ & kó & $k a$ & $k i$ & $k e ́ / / k a^{57}$ & $k e ́$ \\
\hline G & \multicolumn{2}{|c|}{ kéga } & ké & \multicolumn{3}{|c|}{ kéh } \\
\hline $\mathrm{D}$ & \multicolumn{2}{|c|}{ kému } & $k e ́$ & \multicolumn{3}{|c|}{ kén } \\
\hline A & $=\mathrm{N} / \mathrm{G}$ & $=\mathrm{N}$ & kó & $=\mathrm{N}$ & $=\mathrm{N}$ & $=\mathrm{N}$ \\
\hline $\mathrm{L}$ & \multicolumn{2}{|c|}{ kèn } & $k e ́$ & \multicolumn{3}{|c|}{ kéh } \\
\hline I & \multicolumn{2}{|c|}{ kèn } & kó & \multicolumn{3}{|c|}{ kémi } \\
\hline
\end{tabular}

Oblik A jd. m. r. zamjenice za značenje 'živo' jednak je obliku G, a za značenje 'neživo' jednak je N.

U južnim je labinskim govorima zabilježena uporaba oblika ovih zamjenica u uskličnim rečenicama: Ki lépi mladić!; Kó dobró kafé!; Ké véle nógi imaś!

I ove se zamjenice mogu rabiti u neodređenom, egzistencijalnom ili distributivnom značenju, poput upitno-odnosne zamjenice $k i$ 'tko': ${ }^{58} \mathrm{Ku}$ je $k i$ otrók dóbar, njéni je bólji.; Kó beśédo bi réka, śáka mu je valjála.

$\mathrm{U}$ ovu se skupinu ubrajaju i neodređene složene zamjenice izvedene

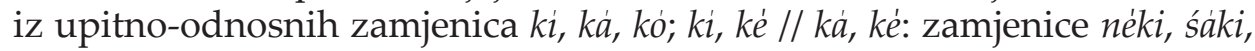
ki gót, málo ki, koje sve imaju i kategoriju roda: $\mathrm{N}$ jd. néki, néka, néko, G jd. nékega, néke, D jd. nékemu, néke, A jd. = N jd. / G jd., = N jd., néko, L jd. néken, néke, I jd. néken, néko, $\mathrm{N}$ mn. néki, néke // néka, néke, G mn. nékeh, D mn. néken, A mn. = N mn., L mn. nékeh, I mn. nékemi; N jd. śáki, śáko, śáka, G jd. śákega, śáke, D jd. śákemu, śáke, A jd. = N jd. / G jd., = N jd., śáko, L jd. śáken, śáke, I jd. śáken, śáko, N mn. śáki, śáke // śáka, śáke, G mn. sáakeh, D mn. śáken,

56 U svim je južnim labinskim govorima u značenju 'iznimno dobro' zabilježen prilog cagódar/čagódar koji je zapravo petrificiran oblik neodređene zamjenice s naveskom -ar- (o podrijetlu toga naveska više v. u Lukežić 2012:52, 227; v. i Nežić 2013:255).

57 V. bilješku 41 ovoga rada.

58 V. bilješku 54 ovoga rada. 
A mn. = N mn., L mn. śákeh, I mn. śákemi; $\mathrm{N} \mathrm{jd}$. ki gót, kó gót, ká gót, G jd. kéga gót, ké gót, $\mathrm{D}$ jd. kému gót, ké gót itd.; $\mathrm{N}$ jd. málo ki, málo kó, málo ká, G jd. málo kéga, málo ké, D jd. málo kému, málo ké itd.

\subsection{Posvojne zamjenice, posvojno-povratna zamjenica, neodređene i pokazne zamjenice}

Prema drugoj se zamjeničkoj sklonidbi u južnim labinskim govorima mijenjaju sve posvojne zamjenice (za 1. 1. jd. mój, mojó // mojé, mojá, za 2. 1. jd. tvoj, tvojo // tvojé, tvojá, za 1. l. mn. náś, náso // náśe, náśa, za 2. l. mn. váś, váśo // vảśe, váśa, za 3. 1. jd. m., s. i ž. r. njegóf, njegóvo, njegóva), kao i posvojno-povratna zamjenica śvój, śvojó // śvojé, śvojá.

Prema istom se sklonidbenom obrascu mijenja i upitna pridjevska zamjenica cegóf/čegóf, cegóvo/čegóvo, cegóva/čegóva, te neodređene pridjevske zamjenice iz nje izvedene: nécegof/néčegof, nécegovo/néčegovo, nécegoval néčegova; nicegof/ničegof, nicegovo/ničegovo, nicegova/ničegova; śácegof/śáčegof, śácegovo/śáčegovo, śácegova/śáčegova; śákokof, śákokovo, śákokova; nikokof, nikokovo, nikokova.

$\mathrm{Na}$ isti se način sklanjaju i pokazne zamjenice: tá, tó, tá, vá, vó, vá te oná, onó, oná; takóf, takóvo, takóva; (o)vakóf, (o)vakóvo, (o)vakóva; ${ }^{59}$ onakóf, onakóvo, onakóva; te upitna zamjenica kakóf, kakóvo, kakóva.

Oblici A jd. m. r. svih tih zamjenica za značenje 'živo' jednaki su obliku $\mathrm{G}$, a za značenje 'neživo' jednaki su N.

U južnim su labinskim govorima veoma česte i pokazne zamjenice složene s -iśt-: 60 taiśti, taiśto, taiśta; (o)vaiśti, (o)voiśto, (o)vaiśta; onaiśti, onoiśto, onaiśta. Kod sklonidbe su ovih zamjenica prisutne dvije mogućnosti. Prva, mnogo češća, sklonidba je samo drugoga dijela ovih složenih zamjenica, pri čemu prvi dio ostaje nepromijenjen (pa čak i u množinskim oblicima): N jd. m. r. taiśti, G jd. m. r. taiśtega, D jd. m. r. taiśtemu, A jd. m. r. = N / = G jd., LI jd. m. r. taiśten, N jd. ž.r. taiśta, GDLjd. ž. r. taiśte, AI jd.ž. r. taiśto, NA mn. m. r. taiśti, GL mn. m. r. taiśteh, D mn. m. r. taiśten, I mn. m. r. taiśtemi, NA mn. ž. r. taiśte, GL mn. ž. r. taiśteh, D mn. ž. r. taiśten, I mn. ž. r. taiśtemi; N jd. m. r. (o)vaiśti, G jd. m. r. (o)vaiśtega, D jd. m. r. (o)vaiśtemu, A jd. m. r. =

59 U spontanu se govoru u svim istraživanim punktovima ovjeravaju oblici ove pokazne zamjenice s početnim vokalom $o$ i bez njega, bez neke zamjetne pravilnosti, premda su oblici bez početnoga $o$ ipak nešto frekventniji. Ispitanici su pak, nakon što su izravno upitani, tvrdili da upotrebljavaju isključivo oblike bez početnoga $o$, no čitava je prikupljena građa pokazala da situacija nije jednoznačna. V. i Nežić 2013:262.

60 Likove pokaznih zamjenica složene s -ist- I. Lukežić definira jednom od jezičnih pojavnosti karakterističnih za »sjeverozapadni čakavski prostorno-jezični kompleks na prostoru hrvatske Istre i Kvarnera« (Lukežić 2012:228, 230). 
N / = G jd., LI jd. m. r. (o)vaiśten, N jd. ž. r. (o)vaiśta, GDL jd. ž. r. (o)vaiśte, AI jd. ž. r. (o)vaiśto, NA mn. m. r. (o)vaiśti, GL mn. m. r. (o)vaiśteh, D mn. m. r. (o)vaiśten, I mn. m. r. (o)vaiśtemi, NA mn. ž. r. (o)vaiśte, GL mn. ž. r. (o)vaiśteh, $\mathrm{D}$ mn. ž. r. (o)vaiśten, I mn. ž. r. (o)vaiśtemi itd. Druga je mogućnost, ovjerena nešto rjeđe, ali ipak zabilježena u svim istraživanim govorima, sklanjanje obaju dijelova složene zamjenice: $\mathrm{N} \mathrm{jd.} \mathrm{m.} \mathrm{r.} \mathrm{taiśti,} \mathrm{G} \mathrm{jd.} \mathrm{m.} \mathrm{r.}$ tegaiśtega, D jd. m. r. temuiśtemu, A jd. m. r. = N / = G jd., LI jd. m. r. teniśten, N jd. ž. r. taiśta, GDL jd. ž. r. teiśte, AI jd. ž. r. toiśto, NA mn. m. r. tiiśti, GL mn. m. r. tehiśteh, D mn. m. r. teniśten, I mn. m. r. temiiśtemi, NA mn. ž. r. teiśte, GL mn. ž. r. tehiśteh, D mn. ž. r. teniśten, I mn. ž. r. temiiśtemi; N jd. m. r. (o)vaiśti, G jd. m. r. (o)vegaiśtega, D jd. m. r. (o)vemuiśtemu, A jd. m. r. = $\mathrm{N} /$ = G jd., LI jd. m. r. (o)veniśten, N jd. ž. r. (o)vaiśta, GDL jd. ž. r. (o)veiśte, AI jd. ž. r. (o)voiśto, NA mn. m. r. (o)viiśti, GL mn. m. r. (o)vehiśteh, D mn. m. r. (o)veniśten, I mn. m. r. (o)vemiiśtemi, NA mn. ž. r. (o)veiśte, GL mn. ž. r. (o) vehiśteh, D mn. ž. r. (o)veniśten, I mn. ž. r. (o)vemiiśtemi itd.

4.5. Zamjenica śá, śó, śá ('sav'), samostalan lik śé i zamjenički pridjev śóm, śómo, śóma

Zamjenica śá, śó, śá ('sav') i zamjenički pridjev śóm, śómo, śóma sklanjaju se također prema drugoj zamjeničkoj sklonidbi, pri čemu je oblik A jd. m. r. zamjenice za značenje 'živo' jednak obliku G, a za značenje 'neživo' jednak je N.

Samostalan lik śé sklanja se na sljedeći način: NA śé, G śéga, D śému, LI śén. Pridjevski lik śó u NA jd. ima nastavak -o, a samostalan lik uvijek u tim padežima ima nastavak $-e .^{61}$

\section{Brojevi}

U južnim se labinskim govorima rabe glavni i redni brojevi, brojevne imenice i brojevni pridjevi. Brojevne se imenice miljór i miljón sklanjaju prema imeničkoj sklonidbi kao imenice $a$-vrste muškoga roda.

Sklonjivi su glavni brojevi jedón, jenó, jená; dvó, dvé; óba dvo, óba dve; tri; cetiri/četiri, cetire/četire, a mijenjaju se prema drugoj zamjeničko-pridjevskoj sklonidbi. ${ }^{62}$

Uz imenice pluralia tantum ovjeravaju se množinski oblici glavnoga broja 'jedan': Imé śon jené brgéśi.; Kupila śon śámo jené budonti.; İman śámo jené úśta.

61 Usp. Houtzagers 1985:104-105; Kalsbeek 1998:173; Vranić 2011:107-108.

62 Usp. Lukežić-Zubčić 2007:40; Vranić 2011:109; v. i Nežić 2013:269. 
Broj jedón $\mathrm{u}$ istraživanim se govorima ovjerava i $\mathrm{u}$ funkciji neodređene zamjenice u značenju 'neki, neodređeni' : ${ }^{63} \mathrm{Na}$ mrkàte vájka kupévan poli jené źénśki od Túpljaka.; Jená zénska mi je právila recéto za tá śtrúdel.; Jedón ślovék te je iskó, ni réka kokó se zové ni nic.

Oblik s. r. jd. jenó ovjeren je i u značenju 'po prilici, otprilike' (u priložnoj funkciji): ${ }^{4}$ Jenó dvé-tri úre móraś hodit do támo.; Śtávin jenó pól litri úlja źa práźit.; Bi je jenó śéś lét va Tólije.

S G jd. imenica m. i s. roda slaže se NAV broja dvó: dvó bráta, dvó śina, dvó śelá, dvó dréva, a s N mn. imenica ž. r. NAV broja dvé: dvé śeśtri, dvézzeni. NAV brojeva tri i cetiri/četiri, cetire/četire slaže se pak s imenicama u N mn. svih triju rodova: tri bráti, cetire śeśtri/četire śeśtri. Osobna je zamjenica u takvim slučajevima u $\mathrm{N}$ mn.: Śte vi dvó śé videli?; Mi tri śmo śkúpa délale.; Oné dvé mlóde śo véle prételice., a u ostalim je padežima u odgovarajućem obliku: Njin dvén tréba pét púti réć da bi kápili.; Tóncale śo célo vréme ś njimi dvémi.

Kod sklonidbe su brojeva óba dvo, obá dve u južnim labinskim govorima prisutne dvije mogućnosti, slične onima zabilježenima kod pokaznih zamjenica složenih s -iśt-. Prva, nešto češće ovjerena, sklonidba je samo drugoga dijela ovih složenih oblika, pri čemu prvi dio ostaje nepromijenjen: NAV óba dvo, óba dve, GL óba dveh, D óba dven, I óba dvemi. Druga je mogućnost, ovjerena nešto rjeđe, ali ipak zabilježena u svim istraživanim govorima, sklanjanje obaju dijelova: NAV óba dvo, óbe dve, GL óbeh dveh, D óben dven, I óbemi dvemi.

Ostali osnovni glavni brojevi $\mathrm{u}$ istraživanim govorima nisu sklonjivi: pét, śéś, śédan, óśan, dévet, déset i śtó.

Brojevi 11-19, desetice 10-20 i stotice 200-900 izvedeni su brojevi: jedanájś, dvanájś, dvajśtidvó, triśti, śedandeśét, dvésto, triśto itd.

Redni se brojevi sklanjaju prema drugoj zamjeničko-pridjevskoj sklonidbi ${ }^{65}$ i imaju oba broja (jedninu i množinu) te sva tri roda (muški, ženski i srednji). U višečlanim rednim brojevima sklanja se samo posljednji broj.

Redni se brojevi tvore od osnova priv-, drüg-, trèt-, cetrt-/četrit- i nastavka -i: proi, drugi, tréti, cetriti/četrti. Ostali se redni brojevi (od 5. do 99.) tvore od osnove glavnih brojeva i nastavka $-i$.

Brojevi od 100. do 900. iznimno se rijetko upotrebljavaju, a tvore se od

63 Takvu uporabu broja 'jedan' I. Lukežić drži jednom od jezičnih pojavnosti tipičnih za »sjeverozapadni čakavski prostorno-jezični kompleks na prostoru hrvatske Istre i Kvarnera« (Lukežić 2012:228, 230).

64 V. Kalsbeek 1998:17; Vranić 2011:110; usp. i Nežić 2013:270.

65 V. Lukežić-Zubčić 2007:40, 46-47. 
osnove odgovarajućih stotica i nastavka -ti: śtóti, dvéśtoti i sl.

U južnim su labinskim govorima ovjereni i sljedeći brojevni pridjevi: dvóji, dvóje // dvojja, ${ }^{66}$ dvóje (GL dvójeh, D dvójen, I dvójemi), tróji, tróje // trója, ${ }^{67}$ tróje. Ti se pridjevi tvore dodavanjem sufiksa -oj i nastavaka osnovama glavnih brojeva, a rabe se uz imenice pluralia tantum te uz imenice koje znače par ili skupinu koja označava cjelinu: dvoji pośtoli, dvóje brgéśi, dvóje hóljovi, dvóje vróta // dvója vróta, tróji śváti, tróje budónti i sl.

\section{Glagoli}

Glagolski oblici južnih labinskih govora uglavnom su podudarni s glagolskim oblicima tipičnima za čakavsko narječje kao cjelinu. ${ }^{68} \mathrm{U}$ morfološkim sustavima svih istraživanih govora zabilježeno je šest jednostavnih glagolskih oblika: infinitiv, prezent, imperativ, glagolski pridjev radni, glagolski pridjev trpni i glagolski prilog sadašnji ${ }^{69}$ te šest složenih glagolskih oblika: perfekt, pluskvamperfekt, futur I., futur II., kondicional I. i kondicional II. Među starijim govornicima svih istraživanih mjesnih govora, izuzev govora Kapelice, još se rabi i svojevrsni relikt imperfekta glagola bit koji sudjeluje u tvorbi pluskvamperfekta.

Za glagolske su oblike u južnim labinskim govorima relevantne sljedeće gramatičke kategorije: broj (jednina i množina), lice (prvo, drugo i treće lice za prezent, a prvo i drugo za imperativ), vrijeme (sadašnje, prošla i buduća), djelomice način (imperativ i kondicional), stanje (aktiv i pasiv) i vid.

\subsection{Infinitiv}

Infinitiv se tvori od infinitivne osnove i nastavaka - $t$ i -ć, npr. beźáat, délat, hitat, kupit, mohàt, nośit, pádat, réżat, śluśat, śtiśnut; léć, nóć, péć, raśéć, téć, obúć.

U glagola kojima osnova završava konsonantom ś gubi se nastavak - $t$ u skupini śt. Infinitivne osnove koje završavaju vokalom ima-

\footnotetext{
66 V. bilješku 41 ovoga rada.

67 V. bilješku 41 ovoga rada.

68 Usp. Moguš 1966:84-103; Finka 1971:56-62; Houtzagers 1985:130-165; MenacMihalić 1989; Lukežić 1996:131-155; Kalsbeek 1998:179-254; Lukežić-Turk 1998:138145; Lukežić-Zubčić 2007:50-63; Vranić 2011:135-223; Nežić 2013:297-372; Kapović

69 Glagolski prilog prošli ne rabi se u južnim labinskim govorima, što je općenito karakteristično za čakavske govore u kojima on više nije živa kategorija (v. Moguš 1966:84; Finka 1971:57; Menac-Mihalić 1989:81, 101).
} 2018. 
ju nastavak -t, kao i one koje završavaju konsonantom -ś- (kojim se pak razjednačila osnova $\mathrm{s}$ dočetnim šumnikom ispred $t$; a kod njih se gubi taj nastavak): beźát (< beźa-), délat $(<$ dela-), nośit (< nośi-), pủknut (< puknu-), réźat (< reźa-), śedèt (< śede-), umèt (< ume-); kráś (< krad-), pléś (<plet-), śós (< śop-); jéś, źét i sl. Glagol trìt /śe/ također ima nastavak -t zbog slogotvornoga $r$. Infinitivne osnove koje su u ishodišnom obliku završavale velarima $k \mathrm{i} g$, a danas završavaju vokalom, imaju nastavak -ć: léć $(<l e g-)$, móć (<mog-), péć (< pek-), réć (< rek-), téć (<tek-).

\subsection{Prezent}

Prezent se tvori od prezentske osnove i prezentskoga nastavka. U južnim su labinskim govorima zabilježena tri tipa prezentskih obličnih nastavaka.

\begin{tabular}{|c|c|c|c|}
\hline & 1. tip & 2. tip & 3. tip \\
\hline \multirow{3}{*}{$\mathrm{jd}$. } & -én // -en & -ón // -an & $-i n / /-i n$ \\
\hline & -éś // -eśs & $-o ́ s ́$ // -aś & -iś // -iś \\
\hline & $-\dot{e} / /-e$ & $-\dot{o} / /-a$ & $-i / /-i$ \\
\hline \multirow{3}{*}{ mn. } & -émo // -emo & -ómo // -amo & -imo // -imo \\
\hline & -éte // -ete & -ote // -ate & -ite // -ite \\
\hline & $-\dot{o} / /$-O & -ójo // -ajo & $-\dot{o} / /-0$ \\
\hline
\end{tabular}

U govorima je južne labinske podskupine zabilježeno poopćenje, odnosno unifikacija nastavka za 3. 1. mn. prezenta na nastavak $-0 .{ }^{70}$

Primjeri prezenta glagola s prvim tipom prezentskih obličnih nastavaka: bodèn, bodéś, bodè, bodèmo, bodète, bodó; pijèn, pijéś, pijé, pijémo, pijète, pijo; tressén, treśés, treśé, treśémo, treśéte, tresso; umrén, umrés, umré, umrémo, umrète, umró; dobijen, dobijeś, dobije, dobijemo, dobijete, dobijo; iśćen, iśćeś, iśće, iśćemo, iśćete, iśćo; móśen, móśeś, móśe, móśemo, móśete, móśo; piśen, piśeś, piśe, piśemo, piśete, piśo; rinen, rineś, rine, rinemo, rinete, rino.

Primjeri prezenta glagola s drugim tipom prezentskih obličnih nastavaka: igrón, igróś, igró, igrómo, igróte, igrójo; kantón, kantós, kantó, kantómo, kantóte, kantójo; kopón, kopós, kopó, kopomo, kopóte, kopójo; krepón, krepós, krepó, krepómo, krepóte, krepójo; źnón, źnóś, źnó, źnómo, źnóte, źnójo; délan, délaś, déla, délamo, délate, délajo; hitan, hitaś, hita, hitamo, hitate, hitajo; móran, móraś, móra, móramo, mórate, mórajo; plávan, plávaś, pláva, plávamo, plávate, plàvajo; śluśan, ślussaś, śluśa, śluśamo, śluśate, śluśajo.

Primjeri prezenta glagola s trećim tipom prezentskih obličnih nastava-

70 Više o o tome v. u Nežić 2013:110-111, 309-310. 
ka: brojin, brojiś, broji, brojimo, brojite, brojó; gorin, goriś, gori, gorimo, gorite, goró; śedin, śediś, śedi, śedimo, śedite, śedo; vrtin, vrtiś, vrti, vrtimo, vrtite, vrtó; źvonin, źvoniś, źvoni, źvonimo, źvonite, źvonó; hódin, hódiś, hódi, hódimo, hódite, hódo; mólin, móliś, móli, mólimo, mólite, mólo; nóśin, nóśiś, nóśi, nóśimo, nósite, nóso; vidin, vidiś, vidi, vidimo, vidite, vido; źóbin, źóbiś, źóbi, źóbimo, źóbite, źóbo.

Negacija se glagola tvori predmetanjem niječne čestice ne, npr. ne délan, ne vidiś, ne rośté, ne gónamo, ne pijète, ne letó.

Svršeni prezent glagola bit $\mathrm{u}$ južnim labinskim govorima glasi búden, búdeś, búde, búdemo, búdete, búdo. U uporabi su isključivo kratki oblici nesvršenoga prezenta glagola $b i t^{71}$ a takvi oblici mogu biti naglašeni i nenaglašeni: śón, śi, jé, śmó, śté, śó; śon, śi, je, śmo, śte, so. Zanijekani je nesvršeni prezent toga glagola neśón, neśi, ni, neśmó, neśté, neśó.

Prezentski se oblični nastavak $-u$ u 1 . l. jd. kao relikt nekadašnjega tematskog prezenta u južnim labinskim govorima ovjerava još samo u prezentu glagola utét, a u uporabi su isključivo kratki oblici prezenta glagola toga glagola ${ }^{72}$ koji mogu biti naglašeni i nenaglašeni: ćú, ćéś, ćé, ćémo, ćéte, ćó; ću, ćeś, će, ćemo, ćete, ćo. Za 1.1 jd. zabilježeni su i oblici ćún, ćun koji se obično rabe kad se oblik pojavljuje naglašen, a isti govornici ovjeravaju i oblik s nastavkom - $u$ i oblik s dočetnim $n$ koji je analoški dodan prema nastavku za 1.1. jd. prezenta sviju ostalih glagola. Takvi se oblici s dočetnim $n$ češće ovjeravaju u govornika starije životne dobi, ali ne isključivo kod njih, a uvijek je prisutna alternacija oblika s obama nastavcima. U 3. 1. mn. u svim je istraživanim govorima pretežit oblik s nastavkom -o, ali kod mlađih je govornika zamijećena i nešto frekventnija uporaba oblika s nastavkom -e, koji se kod starijih govornika bilježi jako rijetko. Povremeno je u uporabi, ponovno u starijoj populaciji, i oblik ćéjo, ćejo za 3. 1. mn. prezenta. Zanijekani prezent glagola utét ima sljedeće oblike: néću (néćun), néćés, néće, néćemo, néćo (néćejo).

Zanijekani prezent glagola imét ima sljedeće oblike: niman, nimaś, nima, nimamo, nimate, nimajo.

\subsubsection{Morfonološke alternacije}

U prezentskim oblicima glagola u južnim su labinskim govorima ovjerene sljedeće promjene konsonanata na dočetku osnove: $k>\check{c}$, odnosno $c$ uslijed cakavizma: plảkat : plócen/plóčen; śkokàt : śkócelśkóče; g >ź: lágat : láźe;

71 Ta se značajka smatra arealnom značajkom i vlastitom unutarčakavskom inovacijom. V. Lukežić 2012:230.

72 I ta se značajka smatra arealnom značajkom i vlastitom unutarčakavskom inovacijom. V. Lukežić 2012:230. 
h>ś: mohàt: móśen; puhàt: puśe. Skupina se śk mijenja u ść: iśkảt : iśćen; pljéśkat : pljéśće; vriśkàt : vriśće. Infinitivna osnova glagola koji završavaju labijalnim konsonantima alternira s prezentskom osnovom u kojoj se ovjerava epentezom dobiveni $l$ iza takvih konsonanata: śćipat : śćiplje. U prezentskim oblicima glagola druge vrste izostavlja se dočetak nerelacijskoga morfema -nu-: dignut /śel : dignen /śe/; obrnut /śel : obrinen /śe/; pùknut : pùkne; śtiśnut /śe/ : śtiśne /śe/. U dijelu glagola kojima osnova završava vokalom, a prezentski nastavak počinje vokalom $e$, na osnovu se dodaje sonant $-j-:$ cutt/čut : cújen/čújen; dobit : dobijen; pit : pijèn; raźbit /śe/ : raźbijen /śe/; śit : śijen, źabit : źabijeś. U dijelu glagola zadržava se u prezentu ishodišni dočetni konsonant (za razliku od infinitiva, gdje su se konsonanti razjednačili pred nastavkom -t u -ś-, a zatim je i $t$ ukinut): bóś : bodén; pléś : pletén; róś : rośtén; śós : śopén.

\subsection{Glagolski prilog}

Kao što je već istaknuto, $\mathrm{u}$ južnim je labinskim govorima zabilježen samo glagolski prilog sadašnji, dok glagolski prilog prošli više nije živući oblik. Glagolski se prilog u istraživanim govorima tvori od osnove lika 3. 1. mn. prezenta i trima tipovima nastavaka s formantom -ć: -ajoć / -ojoć, -oć ili -eć, pri čemu se često bilježi i alternacija nastavaka s vokalom -o- ili -e- u istim primjerima: béroć, beźóć // beźéć, cékajoć/čékajoć, délajoć, drźóć // drźéć, gónajoć, hitajoć, hódoć // hódeć, issćoć, letoó // letéć, leźoć // leźéć, lojoć, nośoć // nośsé, péroć, pijóc, plàvajoć, plócoć/plóčoć, śedoć // śedéć, śopóć, śpóć // śpéć, tóncajoć itd.

\subsection{Glagolski pridjev radni}

Glagolski se pridjev radni tvori uglavnom prema infinitivnoj osnovi kojoj se, osim u jd. m. r., dodaje sufiks -l- te nastavak kojim se iskazuje rod i broj.

U govorima labinske skupine zabilježeni su sljedeći nastavci za tvorbu glagolskoga pridjeva radnoga: $-\varnothing \mathrm{u}$ jd. m. r., $-a$ u jd. ž. r., $-o$ u jd. s. r., $-i$ u mn. m. r., -e u mn. ž. r. te -e ili - $a^{73}$ u mn. s. r., npr. dáva, dávala, dávalo, dávali, dávale, dávale // dávala; peljó, peljála, peljálo, peljáli, peljále, peljále // peljála; nóśa, nośla, nóślo, nośli, nośle, nośle // nóśla; źvó, źvolà, źvoló, źvoli, źvolè, źvolé // źvolá.

\subsubsection{Morfonološke alternacije}

U glagolskim pridjevima radnim dijela glagola izostavlja se dočetni konsonant $d$ ili $t$ ishodišne osnove: bóś (<bod-) : bó, bolá, boló itd.; méś (< met-)

73 V. bilješku 41 ovoga rada. 
: mé, méla (-lo, -li, -le, -le // -la), páś (<pad-) : pó, pála (-lo, -li, -le, -le // -la), plés (< plet-): plé, plelá (-lo,-li,-le, -le // -la) itd. Neki glagolski pridjevi radni glagola koji u infinitivu imaju nastavak -ć zadržavaju ishodišni dočetni velarni konsonant osnove $k$ : péć (< pek-) : péka, peklá, pekli itd.; réć (<rek-) : réka, reklá, rekli itd.; túć (<tuk-) : túka, túkla (-lo,-li,-le, -le // -la). U glagolskim pridjevima radnima glagola nabràt, oprét, pobràt, umrét, źaprét dodaje se paradigmatski analoški vokal $a$ i u jd. m. r.: nábra, ópra, póbra, úmra, źápra : nábrla (-lo, -li, -le, -le // -la), óprla (-lo, -li, -le, -le // -la), póbrla (-lo, -li, -le, -le // -la), úmrla (-lo, -li, -le, -le // -la), źáprla (-lo, -li, -le, -le // -la).

\subsection{Glagolski pridjev trpni}

Glagolski je pridjev trpni zabilježen uglavnom kod glagola svršenoga vida. Tvori se prema infinitivnoj osnovi na koju se domeću sufiksi -n-,-jen-, -t-, -et- ili prema prezentskoj osnovi kojoj se domeće sufiks -en-, a u oba se slučaja dodaju još i sljedeći nastavci: $-\varnothing \mathrm{u} \mathrm{N} \mathrm{jd.} \mathrm{m.} \mathrm{r.,}-a \mathrm{u} \mathrm{N} \mathrm{jd.} \mathrm{ž.} \mathrm{r.,}-o \mathrm{u}$ N jd. s. r., $-i$ u N mn. m. r., -e u N mn. ž.r. te -e // - $a^{74}$ u N mn. s. r., npr. pośójen, pośójena, pośójeno, pośójeni, pośojene, pośojene // pośojena; raźbijen, raźbijena, raźbijeno, raźbijeni, raźbijene, raźbijene // raźbijena; śkủhan, śkùhana, śkùhano, śkùhani, śkùhane, śkùhane // śkùhana; źáprt, żáprta, żáprto, źáprti, źáprte, źáprte // źáprta; źgorén, źgorèna, źgoréno, źgorèni, źgorène, źgoréne // źgorèna.

Glagolski pridjev trpni iskazuje gramatičke kategorije roda (muški, ženski i srednji), broja (jedninu i množinu), padeža te u NV (i A za 'neživo') i kategoriju određenosti, odnosno neodređenosti.

\subsubsection{Morfonološke alternacije}

U glagolskih pridjeva trpnih ispred sufiksa -en- gubi se dočetni vokal osnove. U dijelu glagola zadržani su ishodišni dočetni konsonanti osnove $t, d$ u svim likovima glagolskoga pridjeva trpnoga (naspram konsonanta -ś$\mathrm{u}$ infinitivu nastala razjednačavanjem ispred nastavka $-t)$ : poméś : pometén, pometéna; upléś : upletén, upleténa; źbóś : źbodén, źbodèna. U nekim glagolima provodi se i palatalizacija: $k>c$, odnosno $c$ uslijed cakavizma: obuć : obucen/ obưčen, obucena/obučena; péć : pecén/pečén, pecéna/pečéna; śtuć : śtucén/śtučen, śtucéna/śtúčena; $g>z$ : ośtrgàt : ośtrżen, ośtrźena; źléć : źléżen, źléżena. Za neke je glagole tipično provođenje jotacije: $t>c$ : hitit: hićen, hićena; plotit : plaćén, plaćéna; puśtit : puścén, puśćéna; źapuśtit : źapuśćen, źapuśćena; $d>j$ : pośodit : pośojen, pośojena; rodit : rojén, rójena; $n>n$ n: dignut : dignjen, dignjena; obrnut : obrimjen, obrinjena, pùknut : pùknjen, pùknjena; śtiśnut : śtiśnjen, śtiśnjena; $l>l$ : podelit : podéljen, podéljena; raźdelit : raźdéljen, raźdéljena; $l>l$ iza $p, b$ uslijed epenteze: kupit : kupljén, kupljéna; źgubit : źgúbljen, źgúbljena; źobit : źóbljen, źóbljena.

\footnotetext{
74 V. bilješku 41 ovoga rada.
} 


\subsection{Imperativ}

Imperativ se tvori od imperativne osnove i nastavaka za imperativ u 2. 1. jd. te 1. i 2. 1. mn., a za 3. 1. jd. i mn. rabe se oblici složeni od čestice neka i prezenta glagola.

Dio glagola tvori imperativ nastavcima -ø za 2. 1. jd., -mo za 1. 1. mn. i -te za 2. 1. mn.: délat : délaj, hitat : hitaj, kantát : kantój, kopát : kopój, krepát : krepoj, peljàt : peljoj, plàvat : plávaj, rivat : rivaj, śluśat : śluśaj, śkuźát : śkuźoj, tornàt : tornoj.

Za neke su glagole imperativni nastavci -i / -i // -ø za 2. 1. jd., -imo / -imo // -mo za 1.1. mn. i -ite / -ite // -te za 2.1. mn.: beźi // biźi // biś, ${ }^{75}$ bit : budi, bóś : bodi, brojàt: broji, dàt: dáj, drźát : drźi // drś, ${ }^{76}$ iśkát : iśći, jéś : ji, lájat : loj, leźáat : leźi, mohàt: mośi, nabràt : naberi, napiśát : napiśi, nóc : nojdi, péć : peci, pit : pi, pomóc : pomori, potéźat : potéźi, potrit : potari, prit : pridi, réć : reci, réźat : réźi, śés : śédi, śkokàt : śkoci, ślàt : śálji, śpàt : śpi, śpuhàt : śpuśi, śtót : śtój, tuć : tuci, udrit : udri, upràt : uperi, veźát : veźi, vriśkat : vriśći, źabit : źabi, źét : źami // źámi, 77 źvát : źovi.

Preostali glagoli tvore imperativ nastavcima - $i$ / - $i$ za 2. 1. jd., -imo / -imo za 1. 1. mn. i -ite / -ite za 2. 1. mn.: bolét: boli, dignut : digni, govorit : govori, hodit: hodi, jovit: jovi, letét: leti, obrnut: obrni, oprét: opri, plotit: ploti, potegnut : potegni, právit : právi, pùknut : pùkni, śedèt : śedi, śtávit : śtávi, śtiśnut : śtiśni, śtorit : śtori, umrèt : umri, videt : vidi // viś, ${ }^{78}$ vrtèt : vrti, źaprèt : źapri.

Poseban se oblik nemój u konstrukciji s infinitivom rabi za izricanje zabrane, npr. Nemój źobit!, Nemój jedinemu právit., Nemój fermát. i sl.

75 U svim oblicima glagola beźát u južnim je labinskim govorima zabilježen ekavski odraz jata, jedino su oblici imperativa kojima je naglašen početni slog i jednosložni imperativni oblici ovjereni s ikavskom zamjenom jata (usp. i Nežić 2013:44, 362). U svim su istraživanim govorima zabilježeni trojaki oblici imperativa glagola beźát, pri čemu su oni s ikavskim odrazom jata i naglašenim početnim slogom stilski obilježeni i rabe se prilikom jačega izricanja zapovijedi, a oblici s ekavskom zamjenom jata i naglašenim dočetnim slogom uobičajeni su u stilski neutralnoj uporabi. Oblici biś za 2. 1 . jd., biśmo za 1. 1. mn. te biśte za 2. 1. mn. imaju snažnije izraženu zapovjednost.

76 U svim su govorima obuhvaćenima istraživanjem moguća oba lika imperativa glagola drźat, pri čemu se kraći (s nastavkom -ø) rabi prilikom izricanja izraženije zapovijedi.

77 Oblicima imperativa glagola źet s naglaskom na vokalu nastavka izražava se izričitija zapovijed.

78 U istraživanim su se govorima kao relikti održali i oblici viś za 2. 1. jd. i viśte za 2. 1. mn. imperativa glagola videt. Značajka je to autohtonih sjevernočakavskih govora i takvi se oblici rabe "za izricanje ublažene zapovijedi, a sa zamjenicama u dativu služe za iskazivanje blagoga upozorenja, skretanja pozornosti sugovorniku na ono što traži a ne zamjećuje« (Lukežić 1999:219). 


\subsubsection{Morfonološke alternacije}

U oblicima imperativa glagola ovjerene su sljedeće mijene konsonanata na dočetku osnove: $k>c$ : péć : peci, réć : reci, śkokàt : śkoci, téć : teci, túc : tuci; $g>z$ : léć : léżi; $h>$ ś: mohàt : mośi, śpuhàt : śpuśi. Skupina śk zamijenjena je skupinom ść: iśkàt : iśći, pljéśkat : pljéśći, vriśkat : vriśći. U glagola druge vrste izostavlja se dočetak nerelacijskoga morfema -nu-: dignut : digni, obrnùt : obrni, potegnùt : potegni, puhnut : puhni, raśtegnùt : raśtegni, śtiśnut: śtiśni, źarinut : źarini. U nekim glagolima zadržani su ishodišni dočetni konsonanti osnove $d, t, p \mathrm{u}$ imperativu (naspram konsonanta -ś- $\mathrm{u}$ infinitivu nastala razjednačavanjem ispred nastavka $-t)$ : boos : bodi, pléś : pleti, śéś : śédi, śós : śopi.

\subsection{Relikti imperfekta glagola bit}

U starijih izvornih govornika južnih labinskih govora, izuzev u govoru Kapelice, ovjeren je poseban oblik glagola bit, svojevrsni relikt imperfekta s razvijenim nastavcima prezenta, ${ }^{79}$ koji se pojavljuje u sljedećim likovima: béśen, béśeś, béśe, béśemo // béśmo, béśete, béśo // béśejo. Zabilježena je međutim i uporaba ujednačena lika béśe za sva lica jednine i množine u svim spomenutim punktovima.

Taj se relikt imperfekta glagola bit $\mathrm{u}$ istraživanim govorima nikad ne rabi samostalno već je zabilježen samo u tvorbi pluskvamperfekta (uz tvorbu toga složenoga glagolskog vremena i od nesvršenoga prezenta glagola bit i glagolskoga pridjeva radnoga), i to za one radnje koje su se ponavljale u prošlosti ili bile na neki način uobičajene, tj. za učestale ili iterativne radnje. ${ }^{80}$ Mlađi govornici južnih labinskih govora taj oblik glagola $b$ it ne rabe. ${ }^{81}$

\subsection{Futur I. i II.}

Futur I. tvori se od prezenta glagola utét i infinitiva glagola koji se spreže, npr. iśkàt ću // ćun, mohàt ćeś, dàt će, govorit ćemo, śtiśnut ćete, kantàt ćo // će // ćejo itd.

\footnotetext{
79 Usp. i Finka 1971:60, kao i Nežić 2013:368.
}

80 Ovdje se može uključiti i dio definicije uporabe imperfekta u paškim govorima H. P. Houtzagersa - da se taj glagolski oblik koristi za izražavanje »uzualnosti u prošlosti« (Houtzagers 1987:85; 1991:80), pri čemu dakako treba uzeti u obzir da se u južnim labinskim govorima to primjenjuje isključivo na oblik pluskvamperfekta tvoren posebnim reliktom imperfekta glagola bit i glagolskim pridjevom radnim, a ne na imperfekt općenito.

81 Dobna bi se granica, na temelju ispitanika uključenih u ovo istraživanje, mogla postaviti na 70-ak godina - ispitanici mlađi od te dobi ne ovjeravaju taj glagolski oblik. 
Futur II. tvori se od svršenoga prezenta glagola bit i glagolskoga pridjeva radnoga glagola koji se spreže, npr. búden śo, búdeś vopila, bùde imélo, búdemo priśli, búdete kápile, búdo vrtéli itd.

\subsection{Perfekt i pluskvamperfekt}

Perfekt se tvori od nesvršenoga prezenta glagola bit i glagolskoga pridjeva radnoga glagola koji se spreže, npr. hodi śon, videla śi, dobilo je, tekli śmo, rivále śte, leźáli śo itd.

Pluskvamperfekt se tvori od perfekta glagola bit i glagolskoga pridjeva radnoga glagola koji se spreže, npr. bi śon právi, bila śi źvolá, biló je źgorélo, bili śmo vádili, bilé śte veźále, bili śo ćepáli itd.

U južnim labinskim govorima (izuzev govora Kapelice) starije stanovništvo ovjerava i pluskvamperfekt tvoren od posebnoga oblika glagola bit (svojevrsnoga relikta imperfekta) i glagolskoga pridjeva radnoga glagola koji se spreže, a takav se pluskvamperfekt rabi za izricanje radnji koje su se ponavljale ili su bile uobičajene u prošlosti, tj. za učestale ili iterativne radnje, npr. béśen peljó, béśeś prontála, béśe śe śsrovljảlo, béśemo // béśmo tóncali, béśete tekli, béśo // béśejo priśli itd.; odnosno béśe peljó, béśe prontála, béśe śe śprovljálo, béśe tóncali, béśe tekli, béśe priśli itd.

\subsection{Kondicional I. i II.}

Kondicional I. tvori se od posebnoga oblika glagola bit (bin, biś, bi, bimo, bite, $b i)^{82}$ i glagolskoga pridjeva radnoga glagola koji se spreže, npr. drźó bin, pitála biś, pojálo bi, śkokáli bimo, pekli bite, nóśli bi itd.

Kondicional II. tvori se od kondicionala I. glagola bit i glagolskoga pridjeva radnoga glagola koji se spreže, npr. bi bin pláva, bilá biś plákala, biló bi śe źablátilo, bili bimo póbrli, bilé bite meśále, bili bi ubóśli itd.

82 Taj poseban oblik pomoćnoga glagola bit koji sudjeluje u tvorbi kondicionala u čakavskim govorima jedna je od očuvanih morfoloških značajki kojom se potvrđuje arhaičnost i konzervativnost čakavskoga narječja. Velik broj čakavskih idioma čuva naime stari oblik toga glagola koji je postojao i u praslavenskom i prahrvatskom jeziku, a koji su ostali slavenski jezici i drugi sustavi hrvatskoga jezika znatno izmijenili (Lukežić 1998:41). Uporaba se takvih oblika glagola bit drži kriterijem za određivanje pripadnosti mjesnih govora čakavskomu narječju, odnosno razlikovnom činjenicom najvišega ranga toga narječja (usp. Moguš 1977:100; Lukežić 1996:159; Lukežić 1998:41-42; Lisac 2009:17, 27), pa čak i najznačajnijom i najkarakterističnijom čakavskom osobinom u morfologiji (Finka 1971:60; Brozović-Ivić 1988:84). 


\section{Zaključak}

$\mathrm{Na}$ temelju podataka prikupljenih terenskim istraživanjem detaljno je analiziran morfološki sustav južnih labinskih govora, pri čemu su prikazani i načini tvorbe pojedinih oblika promjenjivih riječi, kao i morfonološke alternacije u oblicima u kojima su one zabilježene.

Imenice se $\mathrm{u}$ južnoj labinskoj podskupini govora dijele $\mathrm{u}$ tri sklonidbene vrste. U sklonidbi je imenica za ove govore karakterističan konzervativizam koji se ogleda u kontinuiranju starih nastavaka: nastavka - e u L jd. imenica svih triju rodova i sklonidbenih vrsta, nastavka - $i$ u G jd. te NAV $\mathrm{mn}$. imenica $e$-vrste, kao i A mn. imenica $a$-vrste, nastavaka $-\varnothing,-i$ i -ah u G $\mathrm{mn}$. imenica različitih rodova i različitih sklonidbenih vrsta, nesinkretiziranih nastavaka za DLI mn. imenica svih triju rodova i svih sklonidbenih vrsta, itd. Posljedica je specifična fonološkoga i morfološkog razvoja sinkretizam A i I jd. imenica e-deklinacije koji se također potvrđuje u svim istraživanim govorima.

U zamjeničko-pridjevskoj sklonidbi za južne je labinske govore tipično prevladavanje nastavaka nekadašnje nepalatalne deklinacije $u$ jednini muškoga i srednjeg roda. Za ženski je rod riječi ove deklinacije također potvrđen već spomenuti sinkretizam u I jd. ženskoga roda, dok je u N mn. srednjega roda uočena snažna generacijska raslojenost: govornici starije životne dobi redovito rabe nastavak -e jednak onomu za $\mathrm{N}$ mn. ženskoga roda, dok mlađi govornici takve oblike rabe izrazito rijetko ili ih uopće ne rabe nego koriste poseban nastavak za srednji rod $-a$.

Istraživani govori pokazuju i neka specifična obilježja u konjugaciji glagola. Ponajprije je tu riječ o poopćenju, odnosno unifikaciji nastavka za 3. 1. mn. prezenta na nastavak -o, zatim uporabi relikta imperfekta glagola bit zabilježenoga u tvorbi pluskvamperfekta u govoru starijih generacija izvornih govornika, kao i postojanju posebnoga oblika glagola bit koji se rabi u tvorbi kondicionala I.

Uz dio morfoloških osobitosti karakterističnih za velik dio čakavskoga narječja kao cjelinu, ovo je istraživanje u južnim labinskim govorima potvrdilo i dio značajki zajedničkih govorima ekavskoga čakavskog dijalekta, odnosno njegova središnjega istarskog poddijalekta te labinske skupine govora, sustava koji su klasifikacijski nadređeni govorima koji su bili predmetom ovoga istraživanja. Usto, dio opisanih morfoloških značajki potvrđuje i pripadnost ove podskupine govora sjeverozapadnomu čakavskomu prostorno-jezičnom kompleksu koji obuhvaća govore u hrvatskoj Istri i na Kvarneru. 


\section{Literatura}

Brozović, Dalibor; Pavle Ivić. 1988. Jezik srpskohrvatski/hrvatskosrpski, hrvatski ili srpski. Zagreb: Jugoslavenski leksikografski zavod »Miroslav Krleža«.

Finka, Božidar. 1971. Čakavsko narječje. Čakavska rič, 1, 11-71.

Houtzagers, Hubrecht Peter. 1985. The Čakavian Dialect of Orlec on the Island of Cres. Amsterdam: Rodopi.

Houtzagers, Hubrecht Peter. 1987. On the phonology and morphology of the čakavian dialects spoken on the Island of Pag. Dutch Studies in South Slavic and Balkan Linguistics (Studies in Slavic and General Linguistics), 10, 69-90.

Houtzagers, Hubrecht Peter. 1991. Imperfekt v čakavskih govorah ostrova Pag. Sovetskoe slavjenovedenie, 5, 77-82.

Kalsbeek, Janneke. 1998. The Čakavian Dialect of Orbanići near Žminj in Istria. Amsterdam - Atlanta: Rodopi.

Kapović, Mate. 2018. Povijest glagolske akcentuacije u štokavskom i šire. Rasprave: Časopis Instituta za hrvatski jezik i jezikoslovlje, 44/1, 159-285.

Lisac, Josip. 2009. Hrvatska dijalektologija 2. Čakavsko narječje. Zagreb: Golden marketing - Tehnička knjiga.

Lukežić, Iva. 1996. Trsatsko-bakarska i crikvenička čakavština. Rijeka: ICR Rijeka.

Lukežić, Iva. 1998. Govori Klane i Studene. Crikvenica: Libellus.

Lukežić, Iva; Marija Turk. 1998. Govori otoka Krka. Crikvenica: Libellus.

Lukežić, Iva. 1999. Razvoj imperativa i prezenta u čakavskome narječju. Rasprave Instituta za hrvatski jezik i jezikoslovlje, 25, 195-222.

Lukežić, Iva. 2000. Lične zamjenice u čakavskome narječju (sinkronijski i dijakronijski uvid). Rasprave Instituta za hrvatski jezik $i$ jezikoslovlje, 26, 99-128.

Lukežić, Iva. 2001. Odnosno-upitne i neodređene zamjenice za značenja 'neživo' i 'živo' u čakavskome narječju. Čakavska rič, XXIX, 1, 21-37.

Lukežić, Iva; Sanja Zubčić. 2007. Grobnički govor XX. stoljeća (gramatika $i$ rječnik). Rijeka: Katedra Čakavskog sabora Grobnišćine.

Lukežić, Iva. 2012. Zajednička povijest hrvatskih narječja. 1. Fonologija. Zagreb - Rijeka - Čavle: Hrvatska sveučilišna naklada - Filozofski fakultet u Rijeci - Katedra Čakavskog sabora Grobnišćine.

Lukežić, Iva. 2015. Zajednička povijest hrvatskih narječja. 2. Morfologija. Zagreb - Rijeka - Čavle: Hrvatska sveučilišna naklada - Filozofski fakultet u Rijeci - Katedra Čakavskog sabora Grobnišćine. 
Menac-Mihalić, Mira. 1989. Glagolski oblici u čakavskom narječju i u hrvatskom književnom jeziku. Filologija, 17, 81-109.

Moguš, Milan. 1966. Današnji senjski govor. Senjski zbornik, II, 1-152.

Moguš, Milan. 1977. Čakavsko narječje. Fonologija. Zagreb: Školska knjiga.

Moguš, Milan. 1982. Čakavština Opatijskog krasa. Radovi Zavoda za slavensku filologiju, 17, 1-14.

Nežić, Ivana. 2013. Fonologija i morfologija čakavskih ekavskih govora Labinštine. Doktorski rad. Rijeka: Filozofski fakultet Sveučilišta u Rijeci.

Vranić, Silvana. 2005. Čakavski ekavski dijalekt: sustav i podsustavi. Rijeka: Filozofski fakultet u Rijeci, Odsjek za kroatistiku.

Vranić, Silvana. 2011. Govori sjeverozapadnoga makrosustava na otoku Pagu. 2. Morfologija. Rijeka - Novalja: Filozofski fakultet Sveučilišta u Rijeci Ogranak Matice hrvatske u Novalji.

\title{
On the Morphology of the Southern Labin Dialects
}

\begin{abstract}
The Southern Labin dialects are a subset of the Labin group of dialects, itself a part of the Central Istrian subdialect of the Čakavian Ekavian dialect. This paper provides an overview of the core characteristics of the morphological system of this subgroup of dialects, which comprises eighteen local dialects in total. Data was collected in field research, and the description of the morphology includes an analysis of the open classes of words: the declension of nouns, adjectives, pronouns and numerals, and the conjugation of verbs. In addition to demonstrating the formation of certain types of open classes of words, the paper also considers the morphonological alternations in those word classes where they have been noted.

Ključne riječi: južni labinski govori, labinska skupina govora, središnji istarski poddijalekt, čakavski ekavski dijalekt, morfološki sustav, morfonologija

Keywords: Southern Labin dialects, Labin group of dialects, Central Istrian subdialect, Čakavian Ekavian dialect, morphological system, morphono$\log y$
\end{abstract}


